\title{
Experience in the Preservation and Development of the Evenki Language in the Evenki Municipal District of the Krasnoyarsk Krai on the Basis of the Analysis of Evenki Archival Documents
}

\author{
Yulia S. Zamaraeva* \\ Siberian Federal University \\ 79 Svobodny, Krasnoyarsk, 660041, Russia
}

Received 15.03.2018, received in revised form 10.08.2018, accepted 16.08.2018

The article presents an overview of archival documents reflecting the features of various practices of preserving and reviving the Evenki language in the Northern districts of the Krasnoyarsk Krai (based on the analysis of documents on education and enlightenment from the Evenki Archive in the Tura settlement). The relevance of the study is connected with the need to obtain the most complete information, revealing the dynamics of cultural and pedagogical practices for preserving the Northern language as the core of the culture of the indigenous small-numbered peoples of the Far North. The analysis of archival documents obtained during the field research conducted in Evenkia in 2018 made it possible not only to disclose the basic trends in the preservation of the Evenki language, their transformation in the period from the 1930s (years of formation of national districts) till the early 2000s, but also to determine the nature of problems of preserving the disappearing language of the Evenki ethno-cultural group at the present time. The results of field studies were processed, as well as the interpretation of the obtained data was made. The authors of the article carried out a critical analysis of the existing scientific research and summarized the conclusions connected with the solution of the problem of preserving and reviving the Evenki language. The publication of a brief summary of a large number of archival documents for the period from the 1930s until now is of special significance.

Keywords: Evenki language, Evenki municipal district, education, cultural construction, indigenous small-numbered peoples of the Far North.

The study was funded by JSC "Vostsibneftegaz" within the framework of the research project: "Revival of the Evenki Language".

Research area: culturology.

Citation: Zamaraeva, Yu.S. (2018). Experience in the preservation and development of the Evenki language in the Evenki Municipal District of the Krasnoyarsk Krai on the basis of the

(C) Siberian Federal University. All rights reserved

* Corresponding author E-mail address: rybka08@bk.ru 
analysis of Evenki archival documents. J. Sib. Fed. Univ. Humanit. soc. sci., 11(8), 1327-1369. DOI: 10.17516/1997-1370-0309.

\section{Introduction}

The article provides the analysis of archival documents devoted to the experience of preserving and reviving the Evenki language in the Evenki Municipal District of the Krasnoyarsk Krai in chronological order, from 1930 to 2000. The article presents historiography by decades ( $30 \mathrm{~s}, 40 \mathrm{~s}$, etc.), each of the eight historical periods is associated with the analysis of materials and archival documents stored in the municipal institution of culture "Evenki Archive" of the Evenki Municipal District of the Krasnoyarsk Krai (Tura settlement). It should be noted that the only uncovered period in terms of the availability of archival documents was the 1990s. As a hypothesis for the lack of archival documents of this period, it can be assumed that the lack of archival documents is associated with the political, economic and sociocultural transformations taking place in this decade in Russia in general and in Evenkia in particular. Since the 2000s the archival documents have just started to form, so there is only one volume from the section "School education in the native languages of the Evenki Municipal District."

\section{Literature review}

At present, most native languages of the indigenous peoples are either in the process of disappearance or in the risk of disappearing from the language picture of the world. In this regard, the subject of preserving the languages of the indigenous peoples of the North compactly living in the territory of the Krasnoyarsk Krai is discussed in a sufficient amount of literature related to preservation problems, to the practices of reviving native languages, creating literature for children and adolescents, preserving heritage of the indigenous peoples of the North and Siberia.

Recently, there have appeared quite a lot of scientific literature devoted to the topic of learning native languages (in particular, Evenki) from the scientific point of view: languages of the indigenous small-numbered peoples of the North, Siberia and the Far East (hereinafter - ISNPN) (Borgoiakova, 2001; Petrov, 2011; Aref'ev, 2015; Beloliubskaia, 2014; Kudashkin, Ivanchenko, 2015 and others); native languages for the indigenous small-numbered peoples of the Krasnoyarsk Territory (Gashilova, Nabok, 2012; Antoshin, 1987; Arutiunov, 1987; Ermolova, 2003; Ivanova, 2004, 2008; Koptseva, Khizhniakova, Reznikova, 2011, 2017, Koptseva, 2014 and others), education in the environment of the ISNPN (Artemenko, 2007; Lapuko, 2008; Akhmetova, 2014; 
Golovin, 2014; Gorodenko, 2013; Sitnikova, 2015), national and language policy in relation to the ISNPN (Chumak, 2008; Alpatov, 2014; Gorelikov, 2015 and others), Evenki Literature (Ogryzko, 1998, 2013; Shprygov, 2005; Khazankovich, 2007, 2009, 2014; Lagunova, 2010; Lizunova, Bulgakova, 2013; Kolesnik, 2014; Marchenko, 2014; Nepomniashchikh, 2014; Troiak, 2014; Kalenchuk, 2015; Seredkina, 2016; Seredkina, Smolina, Kistova, 2017 and others).

In the modern world science, the Evenki culture is studied in various aspects. Long-term field studies in places of compact residence were conducted by D. Anderson (1991, 1998), B. Dolgikh (1972), N. Koptseva and V. Kirko (2014a, 2014b, 2015), N.M. Libakova, A.A. Sitnikova, E.A. Sertakova, M.A. Kolesnik, M.I. Ilbeikina (2014), K.V. Reznikova, Iu.S. Zamaraeva, A.V. Kistova, N.N. Pimenova (2014). The language policy in the field of the Evenki language was studied by L.A. Grenoble, L.J. Whaley (1999), N.A. Mamontova (2014). Various aspects of the Evenki culture related to the native language were analyzed by W.R. Leonard, P.T. Katzmarzyk, A.G. Comuzzie, M.H. Crawford, R.I. Sukernik (1994), T. Safonova, I. Sántha (2011), V.V. Simonova (2012), N. Ssorin-Chaikov (2001), L.J. Whaley (2011) and other scientists.

A large number of studies are associated with the ascendants of the northern languages, teachers and researchers who directly solved the problems of preserving native languages in the environment of the indigenous population in the $20^{\text {th }}-21^{\text {st }}$ centuries: G.M. Vasilevich, N.Ia. Bulatova, Z.N. Pikunova, V.I. Tsintsius, V.A. Gortsevskaia, N.S. Popova, M.G. Voskoboinikov, O.A. Konstantinova, E.D. Polivanov, Ia.P. Al'kor (Koshkin), A.G. Bazanov, N.G. Kazanskii, V.A. Gortsevskaia and A.A. Gortsevskii, L.M. Zak and M.I. Isaev, V.I. Mathis, A.N. Myreeva, A.V. Romanova, A.V. Poshataeva, R.T. Sakova, V.M. Sangi, K.V. Sturov, D.A. Shchapova.

However, the analysis of the archive materials located in the Evenki Municipal District is being conducted for the first time. In this regard, this research is relevant and has the following purpose: to review the archival documents of the Evenki Museum that are connected with the historical dynamics of cultural and social practices of preserving and reviving the Evenki language. A hypothesis of this study is related to the assumption that many of these practices are relevant and, currently, can be restored and modernized for the effective use in ethno-pedagogy for Evenki children, teenagers and youth. A social result of the study should be the creation of conditions for the formation of a positive ethno-cultural identity among the modern Evenki youth.

Materials and methods: the main methods for the study were: photographic evidence of archival documents (during the field expedition carried out by researchers 
and students of the Department of Cultural Studies of Siberian Federal University, Tura settlement, 2017-2018); analysis of archival documents in the municipal cultural institution "Evenki Archive" of the Evenki Municipal District of the Krasnoyarsk Krai; historiography of the experience of preserving and reviving the Evenki language as a textological basis for analysing measures taken to preserve the Northern language in the period from 1930 till 2000; cultural-comparative method of research of archival materials, which revealed the actual content of attitudes and values in the field of cultural enlightenment and education of the ISNPN in historical dynamics.

\section{Results}

Hereby we present a chronological review of archival documents related to the preservation and dissemination of the Evenki language.

The 1930s. Volume "Resolutions of the Krai (Territory) Headquarters on the review of national schools under the Presidium of the Krai Executive Committee, 1931 (114 pages)". The archival documents mainly contain the texts of Resolutions (local education authorities, regional administrations, Plenums of the Krai Council, the All-Russian Central Executive Committee of Soviets, the City Council) on the introduction of cultural plans, on the state of work of cultural and educational institutions (pre-school, "universal school" (general education), schools for adults, Soviet party schools, workers faculties and others), regional summary materials on public education (on the routes of cultural trips and the work of the participants, the Komsomol, on the retraining of liquidators and the course of education, the plan for the development of a seven-year school).

The documents of the People's Commissariat for Education of the RSFSR in relation to the Evenki National District contain a list of key issues: the tasks of the socialist revolution in the Far North, the tasks of cultural construction in the North, the national languages and literacy of the peoples of the North, the programmes and principles for composition of textbooks in Northern languages, the plan for publishing textbooks and mass literature in the Northern languages (Fig. 1, Fig. 2).

Volume "Resolution of the $9^{\text {th }}$ extended Plenum of the Committee of the North on the report of the People's Commissariat of Education of the RSFSR "On the immediate tasks of the cultural construction in the Far North", 1932 (277 pages)". 1932 is the year of the establishment of national districts, therefore large-scale archival documents concerning the education sphere in the Far North regions of the Krasnoyarsk Krai date back to the 1930s. The archive volume begins with a copy of the appeal 


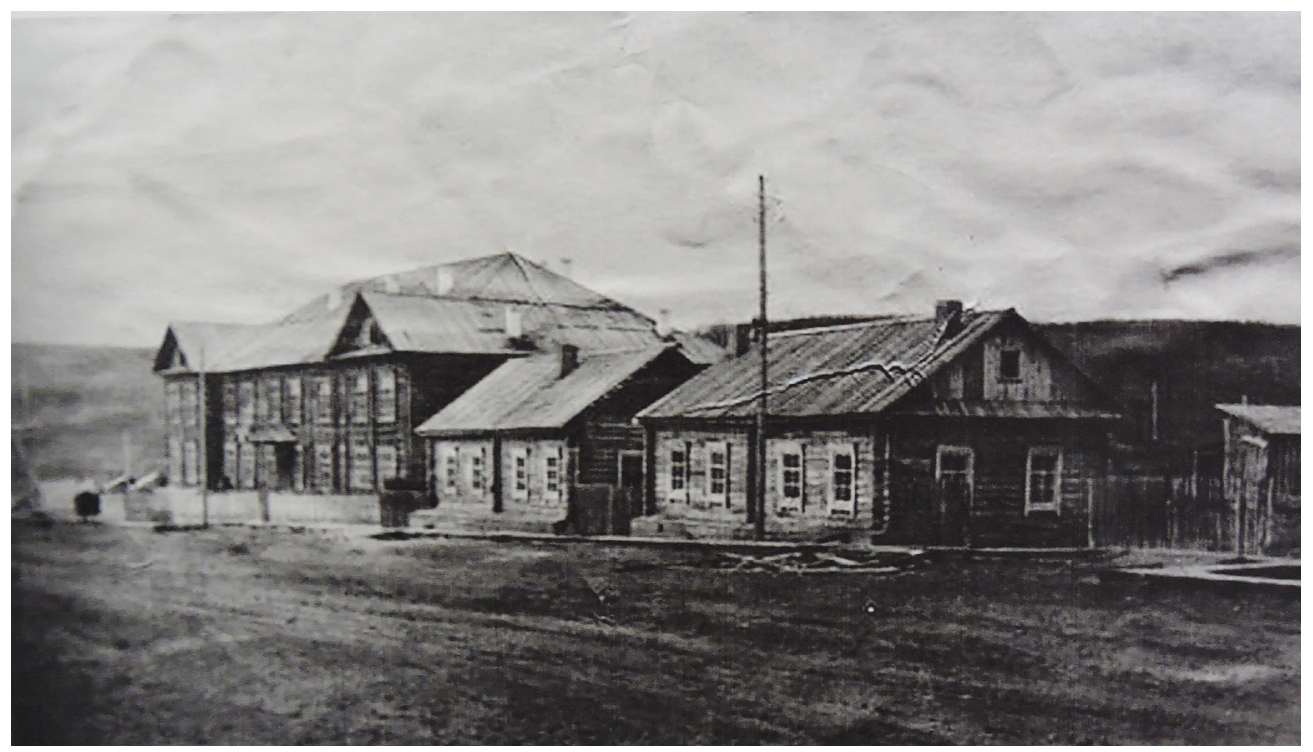

Fig. 1

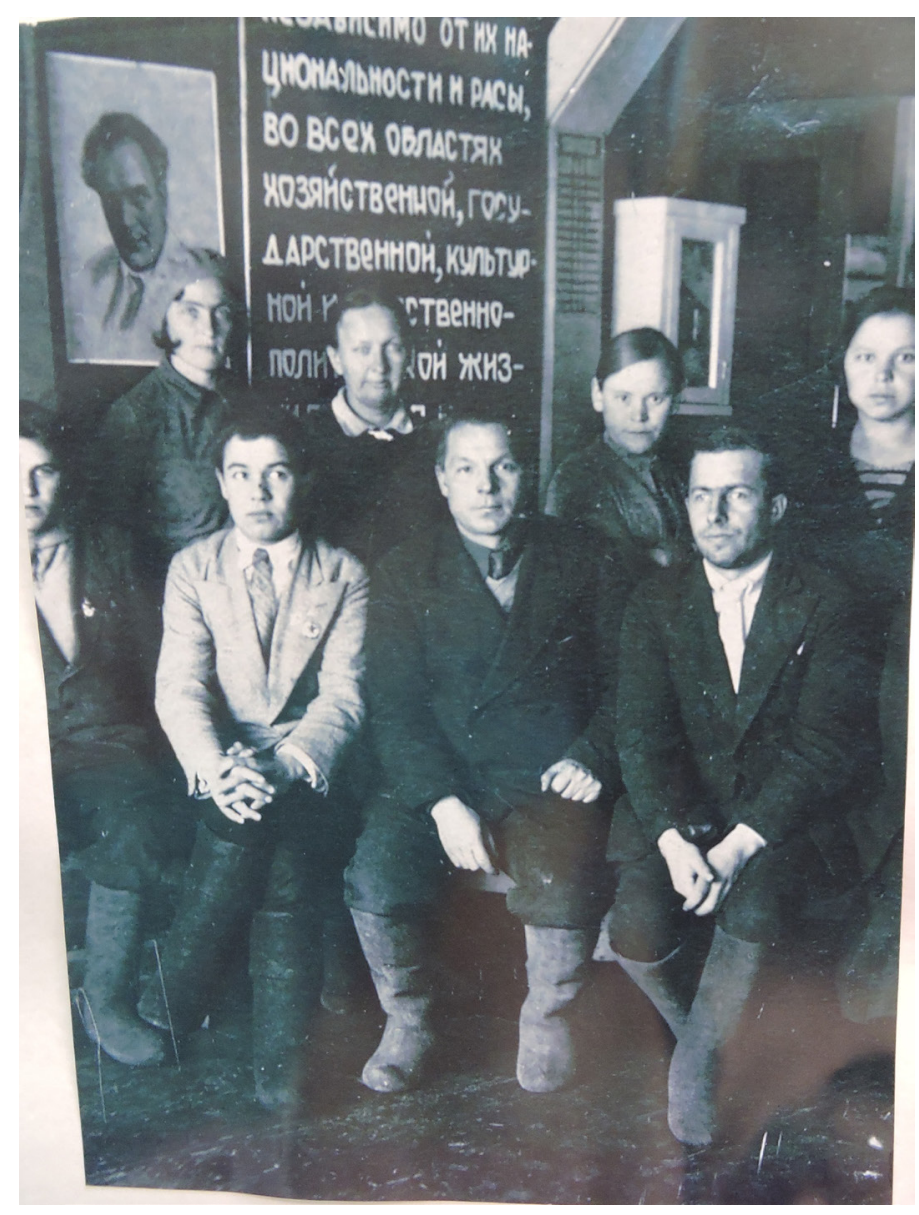

Fig. 2 
document of the People's Commissariat for Education to the Evenki Local Education Authority (December 16, 1932). The text of the document refers to the tasks of the cultural construction in the Far North: reorganization of the network of state budgetary boarding schools into exemplary district schools, revision and expansion of the network of national northern schools within a year before the establishment of one state-budget model school in each national region. The concept of establishing a network of schools was based on the ideas about the polytechnic nature of school education and, at the same time, on its functioning as a methodological centre. For the pedagogical staff of each school, the task is to gather only qualified teachers speaking Northern languages. In the Evenki district it was planned to include three exemplary schools into the state budget: in the settlement of Chirinda of the Ilimpisk District, in the settlement of Baikit of the Baikit District and in the settlement of Strelka Chuni of the Chuni District. In schools it was necessary to organize courses for teachers of the Far North, to form pedagogical libraries and methodical instructions to them and to compile a pedagogical collection. The nomadic schools were to establish methodological support and guidance, to compile a curriculum and programs for the complex technical schools of the North. Guidance on the organization of methodological work of schools was to be carried out by the research association under the Central Executive Committee of the North. The state polygraphic centres were to publish mass literature for school education. The scientific centre for northern pedagogy was Leningrad, the scientific leader in publishing national educational and methodical literature (the Northern branch of the Pedagogical Institute named after Alexander Herzen).

One of the key tasks in the field of education is the elimination of illiteracy in the national districts. As a possible solution to this problem, it was decided to organize shooting of special films for northern cultural institutions, primarily schools. It is planned to organize an expedition to the remote regions of the North in order to study the languages of the peoples of the North (summer 1933).

Thus, the main task of the northern education is mass training of the indigenous population. In this regard, teachers should not only be educated (not lower than the vocational school level), but also those who know the native languages of the northern peoples, who have the opportunity to pursue educational programmes (elimination of illiteracy) among adults and be ready for training in the summer.

The archival documents contain the following entries: "Among the peoples of the North, in the 1932-1933 academic year, the entire core group, all workers, farm labourers and collective farmers, at least $55 \%$ of the poor and middle peasants must be 
taught literacy in their native language, thereby ensuring the possibility to complete the educational program for the North in 1934-1935... Special attention to the educational programme among the nations should be paid to the transfer to education on a new Latinized alphabet."

The concept of cultural construction made it possible to expand the network of schools in Evenkia from 232 to 322 schools (1931-1932), and 185 of them are the indigenous schools. The centres for the creation of national culture of the peoples of the North are the cultural bases that carried out "works of historical importance for creating a written language for the peoples of the North, approved an alphabet for 16 nationalities, released 5 ABC-books, published programs on mathematics and are publishing programs on Russian language and natural science.” The documents from the People's Commissariat of Education declare an urgent demand to study the cultural, economic and social characteristics of each nationality by means of a "maximum differentiated approach to each nationality" in order to "promptly equalize the whole front of cultural construction, to provide maximum assistance to backward nationalities and to promote the full flowering of the cultures of the peoples of the North that are national in form and socialist in terms of the content" (to organize cultural services in the native language).

The archival documents present a draft curriculum for the six-month regional courses on the training of the Soviet core groups to work in the Far North. The following subjects were included in the compulsory list: mother tongue (teaching literacy, writing and literacy elimination), Russian language (in the volume of literacy classes), mathematics, social studies (issues of cultural construction in the North, international and antireligious education in the North), geography, sanitation and hygiene fundamentals, Soviet records management and bookkeeping.

Volume "Guidelines on the illiteracy elimination work", 1933 (207 pages). This document describes the forms of work with students from the first to the third grades of secondary school. Thus, in the first grade, students must acquire reading and writing skills (initial skills in handwriting); to develop oral speech, to work with a picture (to think up captions for a picture), to pass vocabulary works; to get information on grammar. In the second grade the following forms of work with students are offered: meaningful reading (of small printed articles, handwritten texts); development of oral and written speech; initial information on grammar. In the third grade there are following works: reading ("dramatic reading aloud texts from books and pamphlets in the Evenki language"); writing; development of oral and written speech; grammar 
and spelling (based on examples from everyday life: "head of a deer", "riding deer of a teacher", "horns on a deer head", etc.).

In the archival documents there is an Order on taking into account the qualitative indicators of the work of teachers through revision of their payment following the results of the assessment of the annual level of knowledge of the students. The assessment of the quality of work was handled by the rates and disputes commission that was responsible for making a decision to raise or lower the payment. Thus, the document says: "In cases of unsatisfactory performance of these work quality indicators, a reduction in payment by one grade is allowed" (C.1). The highest labour grade was the $4^{\text {th }}$. In 1933 in pre-school institutions, the length of a workday was increased from 4 to 6 hours, and the number of employees was reduced in order to preserve the wage fund and the payment for the allowance of each child in a pre-school institution.

In 1933, the question of conducting educational work with the aim of eliminating the illiteracy of the population through the work of the network of National Education institutions was raised. This network operated on the basis of 7 schools and 12 illiteracy elimination facilities.

The archival documents contain information on the beginning of the work of "cultural construction among the small nationalities of the Far North." The document of July 13, 1932 on the meeting on cultural construction lists titles of the main reports: the second five-year period of cultural construction in the Far North; the state of general education in the North; the indigenization of schools in the Far North (written language, textbooks and teaching aids, training and advanced training for pedagogical personnel); quality drive for the work of schools in the Far North; anti-religious work in schools of the Far North; children's communist movement and children's self-management of students in schools of the Far North; state and tasks of political and educational work among small-numbered peoples of the Far North. The general theme of the reports was public education and cultural construction among the nationalities of the RSFSR. The term "cultural construction" meant the construction of a national culture and a northern culture (culture of the small-numbered nationalities of the Far North). To build a northern culture, the plan for a "cultural outing to the North" was discussed.

In the document "On the Features of the Public Education System for the Nationalities of the RSFSR for the Second Five Years" it is written that further development of national cultures is required, but the main thesis is that "a) there is no special system for educating nationalities, the system is one, with same goals, objectives and content" and "b) considering the specifics leads only to deviations that 
modify the content and scope of programs, the structure of curricula, the terms of training and the duration of the working day for individual types of institutions." In the document there is information on the number of nationalities: "on the territory of the USSR there are up to 200 nationalities, 79 nationalities have a written language, moreover, written languages for 12 nationalities are officially approved; nationalities account for $26.5 \%$ of the total population, there are 12 ASSR, 14 Autonomous Regions, 9 national districts and 132 national areas and about half do not have territorial entities; literacy percentage from $0.8 \%$ to $90 \%$ (Nenets, Yamal district); coverage from $9 \%$ to $100 \%$ (Evenki District)." Thus, there is heterogeneity in national composition (societies with mixed languages), different levels of literate population. This fact is taken into account in educational institutions, since the teaching features are specified: except for the native language, additional languages (one or two) are studied additionally; such disciplines as "history of nationalities", "language and literature of nationality" are introduced.

The state and levels of the education system are analysed:

1) Pre-school institutions and zero groups for nationalities. Nomadic and mobile pre-school institutions (pre-school chums, yarangas and tents) are organized for people living far from industrial regions (nomads and half-nomads);

2) Junior schools ( $1^{\text {st }}$ level). Usually it is a 4-year school with increased program material ("elements of history and geography of nationality"). For certain "culturally backward nationalities" in certain locations, the period of study is 5 years (with a 5 -hour working day) in order to gradually eliminate the actual cultural inequality of nationalities and reduce the duration of study to four years. At the same time, the document describes the mechanism for the formation of boarding schools: "for nomadic and half-nomadic peoples, a nomadic school is retained in one or two first groups with the subsequent transfer of children to a normal nomadic boarding school. There will be no need in nomadic schools (consisting of one or two groups), since after the first two years of the five-year plan, when nationalities are accustomed to giving their children to boarding schools, a sufficient network of boarding schools will be deployed";

3) Seven-year schools. The second and the third language (except for foreign language), geography and history of nationalities are studied in the schools;

4) Technical schools. For the northern nationalities, there are integrated technical schools with the following departments: pedagogical, cooperative-collective farm, Soviet construction, Institute of the Peoples of the North (the latter as a special institution with the prospect of growing into an institution of higher education); 
5) Preparatory courses (at departments and technical schools);

6) Workers' faculties - for individual nationalities it is 4 years of study;

7) Institutions of higher education, where 300 hours out of 450 are given for studying native and the second language (except for foreign language). In institutions of higher education, specialists for territories inhabited by non-Russian nationalities were to be trained;

8) Universities (schools for training Soviet government and Communist Party workers, Communist higher educational institution).

The political education of the Northern peoples was set at a high level, since mobile "red chums" began to work in 1938, which were designed to introduce the idea of the Soviet ideology about socialist construction. Thus, the document "Model provision" (approved by the Deputy people's commissar on February 24, 1938) lists the specifics of the work in details: "The red chum carries out its work in a specially equipped tent: a yurt, a yaranga, a chum; operates all year round moving on certain routes in the areas of settlement of the peoples of the North; when servicing the nomadic (reindeer herding, hunting) population, the red chum roams with this group; the work of the red chum among each population group should last from 10-20 days to 3 months. In addition to explaining the national policy of the Soviet government, the task of political and educational work was to explain the "policy of peace pursued by the Soviet government", as well as to conduct anti-religious work (combating quackery and shamanism, explaining the social essence of the latter, destroying religious ideas by conducting discussions about the universe, the origin of a person and other natural science issues).

Volume "Guidelines on methodical work", "Evenki department of Public education", 1933 (311 pages). This archival document mainly contains information about recruiting the teaching staff (teachers) for district schools, since there were very few teachers at the time. Teachers were needed not only for the stable work of the educational process, but also for the implementation of the concept of public education. Heads of the district schools were asked to quantify the need for teachers, to address the issue of improving the professional level among young teachers and their subsequent consolidation among the staff of a school. In the text entitled "Methodical work in a district and the role of an exemplary school", there is a question of eliminating the fundamental shortcoming - increase in the literacy rate among the new generation of children: "through a properly organized pedagogical process that is based on active methods of work, a school must give the country initiative and active participants in 
the socialist building, and educate a generation that is able to establish communism independently. A school, a teacher, public education authorities have the most important task that is to improve the quality of teaching and upbringing." To improve the quality of teachers' work, the theses have a suggestion about the need to exchange pedagogical experience through reports on the analysis of methodological work in the educational process, a system of open lessons, exhibitions of a "better school experience", publications in the district newspaper and wall newspaper. An instructormethodologist who should facilitate the self-organization of schoolwork carries out the operational method of managing schools. His work is organized and controlled by the district and city methodical commission. As for the countryside, it was impossible to apply rigid, unified methods of work. In most cases, one teacher was engaged with 1-2 heterogeneous groups (by language, age), and he was invited to participate in cluster methodological associations, which should be headed by the best teachers of the cluster.

In addition to addressing the issues of increasing general literacy, in the archival documents there is a ten-page document dated August 1, 1933, titled "Anti-religious work among the peoples of the Far North (compiled from the materials of Professor TanBogoraz and others), in which shamanism is declared a religious prejudice, shamans local exploiters of the population for their own incomes, animism (worship of spirits) as a world view "grown on the basis of the impotence of the peoples of the North in their struggle against nature, on the basis of exploitation of kulaks and shamans, is still in the minds of the working people of the North." Several stories and cases are considered in detail when the shaman's activity is considered as indisputable facts of resistance to socialism under construction.

In a document dated August 23, 1933, there is the Resolution of the $2^{\text {nd }}$ extended plenum of the Committee for National Education "On the results and tasks of national education in 1933-1934." Its important message is that a tremendous cultural uplift is being prepared through the following forms of work: the introduction of seven-year education, the implementation of complex literacy, the "deployment" of a network of preschool institutions, the extensive training of qualified personnel from various nationalities of the territory, "the creation of a written language of textbooks, literature and newspapers for many previously non-literate nationalities, the construction of a school in the native languages of nationalities, the transition to new programs, the establishment of a regime in a school and work on a fixed schedule." At the same time, there is detailed information about the low quality of professional training and the work of teaching staff in national schools: "c) a national school does not provide 
sufficient knowledge of either native or Russian languages, these subjects produce the least academic achievement, there is no variety of methods of work in the national school (there is only one method: question-answer) in the verbal teaching", there are not enough textbooks in the national schools ("there is only one textbook in the native language for 4 pupils in the primary school, very few visual aids"). In connection with these problems, it was decided to purchase and deliver textbooks in the native and Russian languages to schools by August 20, 1933, and also "in order to improve the qualification of teachers, to organize the learning of the Russian language for teachers of the national schools, to organize additional courses and help unqualified teachers, first of all in their work to eliminate the "native shortage" they have themselves."

The archival documents contain an explanatory note dated May 05, 1933, titled "The Tasks of a Foreign Language in a School and Organization of Teaching", which explains the necessity of compulsory studying of one of the foreign languages (English, German, French) by school students in order to realize a slogan "To catch up and outstrip the capitalist countries technologically and economically and to attract the latest achievements of foreign science and technology to the service of socialism under construction." There are methodical explanations on the forms of mastering a foreign language and the basic requirements for students during training.

Volume "Guidelines of the Local Education Authority, the Committee of the North", 1934 (243 pages). The guidelines are focused mainly on the development of public education in the Tura Cultural Base, cultural and educational work among the indigenous population of the district (recommendations on the organization of national boarding schools, the composition of students, on the elimination of illiteracy).

Volume "Decisions of the regional meeting on political education work in the territory, the resolution of the meeting of workers of schools in the Far North "On the elimination of illiteracy and semi-illiteracy in the regions of the Far North", 1939-1940 (186 pages). The decision documents contain a text (dated February 25, 1940) addressed to all the Evenki school teachers in the Evenki District about the instructions of the Presidium of the Evenki District Executive Committee on the necessity of teaching native language in $0,1,2$ grades. The text of the document states: "There are teachers in the district who are actively trying to study the Evenki language and thereby raise the progress of their students. Some teachers have already mastered the Evenki language perfectly. In the Tura Secondary School teaching is conducted entirely in the native language in primary grades. Teacher's knowledge of the Evenki language and teaching in a mother tongue makes it possible to raise the student's 
progress incomparably higher, and vice versa, ignorance of the language and teaching in the non-native language for children in the lower grades adversely affects the progress." For learning the language a teacher is offered a textbook by G.M. Vasilevich and the dictionary of the Evenki-Russian language, as well as textbooks of the primary school in the Evenki language", and further "teachers evading the study of the Evenki language will be regarded as unwilling to fight for students' progress, as ignoring the instructions of the People's Commissariat for District Council, which will contribute to the assessment of their work." There is another document (dated March 25, 1940) on the shortcomings in teaching the Russian language in district schools.

The 1940s. Volume "The Illiterate and the Semi-illiterate", 1941 (63 pages). This archival document provides information about the state of illiteracy and semiilliteracy in the Evenki District (Ilimpiisk, Baikit, Tungus-Chuni districts) as of January 1, 1941. The results present the following data: 1634 illiterate people and 689 semiilliterate people, among them 690 illiterate and 356 semi-illiterate people are studying. The archive contains quarterly reports on the process of eliminating illiteracy in all the northern districts of the Krasnoyarsk Krai (Baikit, Poligus, Tychany, Kuz'movka, Stalino, Ust'-Komo, Kumonda, Kuiumba, Kochesthta, Taimba, Surinda, Chunka, OlenSovkhoz, Vanavara, Oskoba, Chemdal'sk. Strelka, Sol'zavod, Mutorai). There is a record made by the head of the district education authority of the Tungus-Chunw district that the elimination of illiteracy and semi-illiteracy is extremely unsatisfactory. In this regard, it is required to immediately begin the implementation of universal education for adults between the ages of 18 and 29, paying special attention to the pre-conscripts born in 1922-23 and the Evenki who cannot speak Russian. Teaching in schools was conducted only in Russian. The age composition of students: 15-20, 20-25, 25-30, 30-40, 40-50; grades from 4 to 7. The national composition of students: Russian, Byelorussians, Ukrainians, Estonians, Mari, Tatars, Chuvash, Buryat. Students were admitted to schools without any education certificates, but due to different circumstances (adult education in a junior grade, constant work at a factory, long business trips, hunting, logging, etc.) adult students left school, not having finished the academic year. In the winter, the educational process was hampered by "unbearable cold". Many students who missed lessons for good reasons were left for a second year of schooling or for the fall to pass their graduation tests.

The archival volume of documents reflects the situation of the war years: due to the need for funding the front line, schools for adults were transferred into the form of night-school classes and the work of teachers was considered as public. 


\section{"The annual report on the network of schools and school enrolment" volume,} 1941 (107 sheets). The annual report contains the information about the secondary boarding school of the Ilimpiisk region of the Evenk national district as per 20.11.1941. The students of grades $0-4$ were educated at school, the total number of students being 48 (11 students in grade $0 ; 8$ students in grade 1; 9 students in grade 2; 13 students in grade 3; 7 students in grade 4). Their academic achievement rate was $89.6 \%$. The main subjects were Russian (oral and written), Native Language (oral and written), Arithmetic, Geography, Literature, Physics, Drawing, Singing, Natural Science, and History. The school organized the educational work in the form of societies in the areas of needlework, physical education, mathematics, and drawing. It is written that the school library was not sufficiently provided with books. Yet, it was fully equipped with textbooks and notebooks. The language of teaching was Russian; the academic performance was $100 \%$. In the course of the year the teachers' councils and parent meetings were held, social work was done. The report also provides the information on the number of schools in 1941-1942. There were 6 primary schools with 26 grades in rural areas (Tura, Essey, Akay, Chirinda, Kochumdek, U-Ilimpia schools), the average number of students being 248. The junior secondary schools were the following: 1 school for grades 1-4 (5 classes, 92 students), grades 5-7 (1,3 classes, 16 students); 6 boarding schools with 275 resident students in the first half of 1941, 235 resident students in the second half of 1941, 250 resident students in the first half of 1942, 239 resident students in the second half of 1942); 1 regional school curriculum office; 1comprehensive school of advanced type for adults in rural areas that provided education for 3 grades only (these were grades 5-7, there were no grades 8-10). "The elimination of illiteracy" section was given a special focus: in 1941 the number of students taught and educated was the same (64 pupils) whereas in 1942 the number of the students taught was 212 but only 72 students finished the academic year.

In the 1940s elimination of illiteracy was given a dominating focus in the field of education. Its aim was to preserve the Russian culture and the Russian language of the Soviet nation. The document "The speakers' instructions at the August regional teachers' meetings on the issue of "Implementation of the order of the People's Commissariat No. 1942 dated 23.12.1940 on the measures to improve the teaching of the Russian language in primary and junior secondary schools" runs: "A good command of the language is a necessary condition for mastering the riches of science and culture, for creative practical work after leaving school. That is why the issues of the students' illiteracy are currently raised as the issues not only of pedagogical, but of great state 
and political importance". The documents define the Russian language as the "native language" which should be mastered through the forms of efficient systematic study both in class and at home, the forms being literary reading, the students' written works, and grammatical analysis. Implementation of the programme of literacy improvement was dwelt upon in "Uchitel'skaya gazeta" ("The Teachers' Newspaper"), discussed at scientific and pedagogical conferences and meetings on language teaching methodology and inexperienced teachers' training which were held in regional settlements. According to the document, literacy is still low despite raising the academic achievement in some schools (p. 3). It is concluded that "improvement of the students' literacy, which is the most urgent problem in the krai, is slow and unsatisfactory". The recommendations set out such steps to improve literacy as organization of extracurricular reading, recommendation of books, collective reading, rural conferences, implementation of the unified spelling regime at schools, improvement of methodological assistance to teachers, and organization of socialist competition between teachers, classes, schools.

The archival documents of 1941 present the report on the work of the Ilimpiisk district (the period from 01.09.1941 till 20.06.1941), which contains the information about "non-Russian schools": "there are 6 non-Russian schools in the region (4 primary and 2 senior schools), the number of the i schools is 5, and the Yakut ones are 2. 411 students study in non-Russian schools". It is written that the schools introduced additional teaching of the native language (Evenki and Yakut): "this subject is basically taught by the teachers who do not know the students' native language... teaching the native language is complicated by a complete lack of school programmes for this subject". The information about boarding schools is the following: there are 6 boarding schools in the area with 439 residents, 239 of them being the Evenks, 139 - the Yakuts, 61 - the Russians. Additionally, organization of readings and discussions in the village reading rooms, propaganda rooms, propaganda tents (while visiting the trading stations), libraries, and clubs made political and awareness-raising work possible in the area. 4,772 people were involved in this work, 363 various topics were discussed with the population (p. 42). At that, the conclusion once again mentions the low level of the executive staff's education and lack of staffing in the institutions.

In the report of the Agata school (for the first half of the 1941-1942 school year) there is some information on mastering the native language: "The preparatory class is taught in the native language; the native language is used in grade 1; the students of grade 2 have the lessons of their native language, Arithmetic is partially taught in the native language; the students of grade 3 have the lessons of the Native Language and 
all the rest subjects are taught in Russian. The teachers have been learning the Evenk language" that helped in their work with the students (p. 56).

"Training of the illiterate and semiliterate" volume, 1946 (Ministry of Education of the Evenk okrono (district public education authority)), (30 sheets). The documents contain the data about the results of the school year, military physical training, school libraries and facilities, foreign languages teaching, network and children body of kindergartens, quarterly summary of orphanages; registration and placement of children left without parents; report of the evening primary and seven-year schools for the rural youth; the summary report on evening primary and seven-year schools, the monthly report on work, the 1945-1946 report on training and retraining courses. The data recorded were necessary to understand the situation on the rate of elimination of illiterate and semi-literate residents, the number of those who were getting their education and those who failed to finish their academic course.

\section{"Correspondence with the kraiono (the krai public education authority) and} the Ministry", 1947. The text of the report of P.P. Ponomarev, the head of the Evenki okrono (district public education authority) in Krasnoyarsk krai, gives a detailed description of the situation with the schools: "The Evenki national district comprises three regions: Evenk (Tura village, the centre of the region and the district), Baikit (Baikit village, the centre) and Tungus-Chuna (the village of Vanavara, the centre) regions. The distance from the district center to the regional center of Baikit is 700 $\mathrm{km}$, to the village of Vanavara $-900 \mathrm{~km}$. The localities (trading stations) where the schools are located far from each other... there is no connection with these schools from May to November. It is only possible in winter in a reindeer sleigh through the taiga. There is also no communication with the regional centres in summer. These transport obstacles prevent from a systematic control over the work of schools as well as practical methodological assistance to them. This is only possible between November and April". The text of the report is full of questions about how it is possible to carry out the inspection of schools, to implement a programme of general education, to fulfill the orders of the regional board of education, etc.

Another report from March 20, 1947, addressed to the Ministry of education from the okrono of Tura village, refers to the state of education of the children of the indigenous nationalities (the Evenks, the Yakuts) which is "still clearly unsatisfactory in the national schools of the Evenk district as evidenced by the following facts: $50 \%$ of the students enrolled in the grade 1 reach grade 4, the rest drop out in the course of 4 school years because of poor progress and diseases". The table further presents the 
following data: 95 students got enrolled at grade 4 in 1940-1941, 86 students finished grade 4; 51 students enrolled at grade 5; in 1941 - 90/81/26; in 1942 - 107/89/28, in $1943-120 / 83 / 62$, in $1944-84 / 54 / 44$. According to the data, the children of the indigenous nationalities reach grade 7 in their minimum number. The report says that "no child of the indigenous nationality has finished the secondary school for the entire existence of the district. Such situation with the teaching of students of different grades is explained by the lack of necessary conditions for actual indigenization of national schools: in 16 national schools out of 18 the language of teaching is not native but Russian, the programmes are for the Russian schools and the textbooks are in Russian, the teachers speak only Russian since the teachers who speak the native language is only 8 in the district.

The collection of the archival documents contains the list of students of the 19461947 academic year, who were sent to the northern schools.

"The reports of the okrono (district public education authority)" volume, 1948 (43 sheets). This archival collection of the district public education authority's reports gives detailed recommendations on how to run the educational process in regional schools and analyzes the causes of the students' poor progress. For the first time it provides the information about the education of children of the indigenous nationality, the case of the Evenk children's boycott to the Russian teachers, violation of school discipline, the distance that appeared between the school and the students' parents. There is a note handwritten in pencil below the report: "Serious help of the okrono on behalf of the executive committee of the district council is needed, the help involving the assistance in establishing the political and educational work among the teachers". The following document of the 1947-1948 annual report of the Evenk district on the work of schools in the Evenk national district lists the outstanding tasks: non-fulfillment of the law on general compulsory education, poor quality of education in some schools regarding such subjects as History, Physics, Chemistry and Mathematics; weak level of knowledge among the students living in trading stations; low level of the teachers' pedagogical work with the students and absolutely insufficient work with the parents; formalism in educational and pedagogical work; low control over the work of schools in general and that of individual teachers on the part of school administration and boards of education. At schools there are almost no visual aids, children's literature; there is a complete lack of methodological literature; notebooks and stationery (chalk, pencils, pens, quills, and ink) are delivered late. Due to the lack of sufficient volume of kerosene the lessons at schools were shortened or they were cancelled because 
of short daylight hours in winter. As for the national schools, their most important task was to teach children of preparatory classes in their native language in order to introduce the Russian language in the course of 2-3 years. To teach children the teachers of preparatory classes were annually trained in Evenk at the regional teacher training courses. Children from distant territories (trading stations, reindeer pastures, hunting raw-hide tents) were specially gathered and brought by the beginning of a school year to get their education. The indigenous population of the Evenks and Yakuts led a nomadic and semi-nomadic way of life. So, boarding schools were established at each school. 24 boarding schools were built from 1934 to 1948. 10 primary schools out of 19 taught their students in the native language from 1947. The programmes were those developed for the Far North, the curriculum was also designed for the schools of the North. However, the document contains a phrase that "poor progress of the students of the indigenous nationality largely depends on the fact that the students of grades 1-2 are taught in Russian due to the lack of the national staff. There are only 10 teachers in the district who speak the language of the indigenous nationality". Another pressing problem concerning the methodical work in regional schools was the inability to deliver the required materials on a timely basis and in sufficient quantity and to be constantly in touch with the regional centres: " $1-2$ teachers work in the remote corners of the trading stations and live there for 3-5 years without leaving the place, the inspector visits the school once every 2-3 years because the staff of inspectors is not complete in the North. Schools do not have the necessary methodological materials, fiction and children's literature. Newspapers and magazines are delivered arrive to the trading stations with a long delay (2-3 months)".

By the beginning of 1949, the number of schools in the area was 31 ( 3 secondary and 25 primary ones), including 2 seven-year schools in Tura and Baikit which were purely national, the Evenk ones and 1 seven-year Yakut school in Essey. The rest of the schools were nationally mixed. To implement the general compulsory education programme it was recommended to continue the in-depth study of the native language in grade 11: "starting from 1949-50, it is necessary to introduce grade 11 on the basis of the Tura secondary school to train teachers who speak the language of the indigenous nationality (Evenk). In addition, it is necessary to run the refresher courses for primary school teachers at each school in the course of the next 5 years".

The next document of the report gives a detailed analysis of the works by the students of grades 1-5 in all regional schools and evaluates the teacher's work providing the examples of how a teacher conducts his/her lessons, what successes and shortcomings 
he/she has. In general, the report identifies weaknesses in training with the aim of their future correction by both the school management and the teachers themselves.

The document of the annual report of the Evenk district public education authority on the work of the district non-Russian schools in the course of the 1947-1948 school year gives the information on schools and pedagogical work there. A total of 28 schools which are provisionally divided into schools of the Evenks, mixed schools with the predominance of Russian and Evenk children. The national schools are 7: "The Tura seven-year school, the Baikit seven-year school, the Poligus forest primary school, the Agata, Chirinda, Chemdal'sk forest (Evenk) school and the Essey (Yakut) school. There are no non-Russian schools". 16 mixed schools educate 1025 students, 252 of them are the Evenks. As for teaching, the document states: "In national schools teaching in preparatory classes of some schools was in the national language, teaching in grades 0-3 in seven-year schools - in the national language, all other grades were taught in Russian and according to the Russian programmes". As for the pedagogical staff, the document runs that 1 teacher speaks the Yakut language, 6 teachers are the Evenks, 10 teachers have studied the Evenk language while working in the North. The national schools always had boarding schools. However, according to the document, the number of the indigenous children is insufficient for some reasons. These are poorly equipped boarding schools, lack of those who know the national languages, lack of textbooks in the native language, lack of methodological work with the teachers (working at the national schools). All the reasons resulted in an unfavorable situation for mastering the Russian language by the students, "moving up to grade 5, the children either repeated the programme of grade 4 to study the third or fourth year, or left to their parents for the raw-hide tent or moved to short-term educational institutions of particular specialization that gave them an opportunity to work in the collective farms they came from. There are no school libraries at national schools".

"The decisions of the executive committee of the district council on the results of work of schools in the Evenki national district" volume, "A brief outline on the state and development of public education in the district in the course of 19301940" (116 sheets). The report of January 2, 1941 highlights the impressive results of the work of the Evenk national district, especially in the field of public education. The document records that the territory of the Evenk national district got covered with a network of schools, reading rooms, libraries, propaganda tents, clubs, etc. during the course of ten years of the administrative initiative, "the growth of a network of schools contributes to the completion of general compulsory education", etc. However, the next 
document "On the state of political and awareness-raising work in the district" states that only some improvements took place, "there still remain a number of significant shortcomings in the work of political and awareness-raising establishments".

The 1950s. "The report on the elimination of illiteracy and semi-literacy in the district" volume, 1950 ( 59 sheets). The report provides the detailed information about the work of night school for the rural youth within the period from 14.11.1949 to 01.01.1950. Young people enrolled in 4 grades (grades 2-3, 5, 6 and 7), their attendance and academic performance were examined. There are instructions for final examinations in the following subjects: Russian, Aalgebra with Arithmetic (grade 7), Russian (grade 6), Russian and Arithmetic (grades 5 and 4). There are data on training in the areas of Ilimpiisk (B-Porog, U-Ilimpia, Vivi, Amo, Agata, Tutochany, Ekonda, Essey, Uchami, Chirinda), T-Chuna region (the trading stations of Vanavara, Chemdsivsk, Ugonyan, Oskoba, Strelka, Mutorai, Kerbo), Baikit region (11 trading stations). Thus, the coverage of the northern regions is expanded, and guidelines for the methodological work on illiteracy elimination are sent. Komsomol members go to the places of reindeer herding and hunting brigades' compact residence to implement a programme of general compulsory education. In the 1950-ies, the problem of illiteracy elimination remained serious. Therefore, the plan of illiteracy elimination in the Evenk national district for the years of 1950-1953 states the step-by-step points:

- illiteracy elimination posts should be established in schools and reading rooms in those trading stations where there are schools. Schoolmasters or heads of reading rooms should be appointed the heads of these points;

- cultural soldiers should be appointed at each point from among the local intelligentsia (teachers, village librarians (izbach), propaganda tent educators, medical men, veterinaries);

- the period of teaching an illiterate should be 5 months, teaching a semi-literate7 months;

- the regions should be recommended to organize the most fruitful work during the national and summer period from April to September. In winter, the work on teaching the illiterate and semi-literate should be carried out individually in brigades.

"Correspondence of the Evenki district department of public education with the higher bodies of public education and other public education institutions" volume, 1953 ( 20 sheets). The text of the explanatory note dwells on the need to study Native Literature in national schools: "Native Literature, which is close and clear to children, should hold a firm place among other subjects in the educational process 
at the national school. The programme of Native Literature for grades 4-6 includes literary pieces of the Evenki folklore and literature. The programme material, selected in compliance with the educational and pedagogical tasks, is aimed at introducing the people's spiritual values to the students and expanding the students' horizons for them to feel the beauty of their native language, learn more about their people's life".

So, in grade 4 the students got familiar with the fairy tales about animals ("pimnakar"), tales about a human or involving a human ("nimacunakar"), folk superstitions and sayings ("gunmukil", one of folklore types). The text says that the main content of fairy tales about animals was praising the force, mind, tricks, and animals. These fairy tales were educational. The main content of fairy tales about humans was reflection over the Evenks' fishing life, the theme being the dream about a happy life, a protest against social injustice.

The fairy tales were intended to form a real picture of the world and, thus, described the hunters' life. The heroic legends ("ulguril") with the introductions in a prose style (in contrast to the heroic epic tradition, where the introductions were poetic) were intended to glorify the heroes. The epic work ('Kheveke") was discussed in the classroom by the students and the teacher (e.g., the pupils studied "Tarpanindia", a large epic work, on the material of which different forms of analysis were applied).

The 1960s. "Correspondence of the Evenki district department of public education with the higher bodies of public education and other public education institutions" volume, from 1953 (20 sheets) (till the end of the 60-ies of the $20^{\text {th }}$ century). Basically, all the pages of the document present a detailed curriculum for each grade in regional schools, indicating the types of work with the students, lists of literary texts for reading.

The 1970s. "Correspondence and instructions on the issues of the native and Russian languages, 1975-1976" volume, (182 sheets). The record from July 03, 1974 presents the results of the 1973-1974 school year in schools in the Ilimpiisk and Baikit regions of Krasnoyarsk krai. 1736 students studied in Ilimpiisk region in the Tura secondary school and boarding school, Essey, Ekonda, Nidym, Noginsk and Uchami schools. In addition to full-time education, there was an eight-year part-time (evening) education. Difficulties in the evening educational process were mainly due to the fact that many residents worked in the taiga conditions and could not visit the evening school. The report noted the secondary school students' low performance, lagging behind the programmes, difficulties with the teaching staff and their pedagogical work, and the students' dropout for various reasons. In the 
Baikit region there were 820 students, 263 inmates of boarding schools, 59 teachers. However, in the schools of this region the level of academic performance was also low ("the quality of knowledge is lower as compared with the previous year", "the school leavers from the Baikit region cannot be sent to the universities because of poor knowledge"). There was also a large dropout of students of the indigenous nationality (" 10 students out of 18 ones of the indigenous nationality were flunked out in grades 9-10"); the beginning of a school year was untimely ("every year on September 1 many children do not go to school; apparently, suglany should be scheduled earlier"). The final documents summarize the conclusion that there are certain changes in public education in the area, but they "do not meet modern requirements yet. We are not ready to move to the secondary education within this five-year plan". The issue of young people's education and transition to general secondary education was quite serious as it was a task set by the party and was of a national character: the state did not promise a decent paid job to an uneducated person. The pedagogical staff took various measures to attract adults to get secondary education (individual interviews, meetings, socialist competitions, etc.). The "Suggestions" document provides with recommendations about the urgency of carrier counseling among school leavers for enrollment to institutes and colleges; about prohibiting the students with low academic achievement to enter the colleges.

In 1975, the sector of the schools of the North at the Research Institute of National Schools of the Ministry of Education of the RSFSR did a great job when they collected and analyzed the students' written works, sent from the district schools, with the aim to study the current state of knowledge and skills the primary school students of the indigenous nationalities of the North demonstrate in the Russian and native languages. Moreover, there are documents that refer to the field trips of the researchers of the Research Institute of National Schools to regional schools, which were aimed at conducting lessons in the Evenk language.

In summer of 1975, in the letter of the Evenki district department of public education to the Ministry of Education of the Russian Federation it is requested to reprint the Russian-Evenk and the Evenk-Russian dictionaries (10,000 copies each).

There is a document that approved the authors of the Evenk language textbooks (dated December 19, 1975): the Evenk language textbook for grade 4 by N.Ya. Bulatova, A.T. Lapuko, the literary reading textbook for grade 4 (a reader) by N.I. Khutokogir, A.T. Lapuko, the Evenk language textbook for grades 5-6 by V.D. Kolesnikova, Z.N. Pikunova, L.I. Ivanova. 
The archival documents contain the programme of the Evenki language in Literature (for grades 4-6) mentioning the forms of work at the texts, giving the titles of the texts (folk fairy tales, riddles, literary fairy tales of the Evenks, poems) and indicating the number of hours for each form of work. There is also a booklet of a textbook for reading in the Evenki language in grade 4 (dated August 13, 1976.). The document outlines the key task of the textbook: "to equip the students with certain knowledge in the fields of phonetics, vocabulary, syntax, word formation and morphology... When covering the topics a special attention will be paid to those phenomena of the Evenki language, which initially have differences from the identical phenomena of the Russian language but at the same time are influenced by it".

There is a review on the Evenki language textbook for the preparatory class by A.F. Boitsova, A.A. Kudria, A.V. Romanova, which is recommended as a new handbook for children of preparatory school age and comprises the texts on the topics of the Motherland, peoples' friendship, modern North and its workers. There is a review on Z.N. Pikunova's manuscript of the collection of dictations and summaries for grades 1-3 of the Evenki primary school. The review is followed by the minutes of the meeting of the educational and methodological council of the Evenk national district dated June 25, 1975 with the analysis and discussion of the Evenk language textbook for grade 0. The conclusion states the decision that the textbook is recommended for publication and circulation increase.

Publication of a comprehensive textbook on the Russian language for the preparatory and first grades of schools with the native and Russian languages as the languages of teaching became the result of great work of the methodologists, scholars and the Ministry of Education. The publication was prepared by the Research Institute of National Schools of the Ministry of Education of the RSFSR. The textbook included:

- a student's book based on the topics of the preliminary oral course;

- wall pictures (25 pieces);

- didactic handouts;

- a set of records with the texts for listening and memorizing by heart, exercises for mastering pronunciation and developing the skills of oral Russian speech;

- a teacher's book with recommendations on using the textbook.

In 1976, the document on methodological work of the Evenk district methodology centre in 1976-1980 was registered. The methodology centre had to promote the integration of the methodological work in regional schools at mastering the native and Russian languages. In 1979, the scientific and practical conference "Ways to improve 
the efficiency and quality of teaching the native and Russian languages" was held. "The Book for reading in grade 1 at the schools of the Far North" by A.F. Boitsova, L.A. Varkovitskaia and A.S. Egorova was discussed at the meeting of the educational and methodological council (the minutes from January 30, 1976, the village of Tura) of the Evenk district department of public education. The archival documents confirm that the methodologists in mastering the native language promoted the decision on the introduction of the Evenki language programme (there is a review of the programme, a letter to the Ministry of Education of the RSFSR with the manuscript and the minutes of the decision of the North sector of the district department of public education. There is also a letter from the Research Institute of National Schools of the Ministry of Education of the RSFSR (1976) about the need to record (audio, text) retellings of three texts by different students of the indigenous nationality (1 class in Evenki, 2 - in Yakut, 3 - in Russian) in order to determine the level of the oral Russian speech the students of primary classes of northern schools demonstrate.

Such document as "The list of fiction in the Evenki language" gives the titles of the texts (books, stories, fairy tales, folklore), dictionaries (41 titles) in the Evenk narration.

The 1980s. "The minutes of the meetings, plans, reports of the council on national education at the department of education, 1980" volume (15 sheets). "The information note on the national schools of the Evenki autonomous district and the work of the author's team at the district department of public education" provides the information about the state of the Evenki language mastering at schools, as it was important to take measures to preserve the native languages for the indigenous population. Thus, there given the data that only 965 students out of 3375 are representatives of the indigenous nationality (mostly the Evenks and a few Kets). Teaching in the native language (Evenki) is characteristic of 13 primary schools out of 28. 120 teachers of 465 ones are of the indigenous nationality. In the boarding school of the village of Tura 201 students of 270 are of the indigenous nationality. The team of authors developed the textbooks and books on understanding and development of the Evenki speech for younger students and worked out exemplary lessons on coherent speech development for senior school for publication. The district schools introduced the teaching of the native language from preparatory class to grade 8 including.

The review on the author's abstract "The problems of primary school teachers' training in the autonomous districts of the Far North (1958-1977)" by N.I. Meliakov is considered an interesting document which was first found among the archival documents. 
"Materials on the work of national schools (plans, reports, analyses), 1983" volume (15 sheets). The paper starts with a telegram of the Ministry of Education of the RSFSR of January 11, 1984, which contains only one phrase of the recommendation of the district department of public education to develop the Evenki language programme for the Evenki primary school (the village of Tura). It is followed by the archival document "On the state and measures for further research of the Evenk language teaching at schools of the Evenki autonomous district of Krasnoyarsk Krai", which defines an important role of learning the native language as a means of education, and the role of the Russian language is defined as the language of international communication. The author of the document is V.E. Chepalov, the chairman of the executive committee of the council of people's deputies of the Evenki autonomous district. He argues that bilingualism has always been a phenomenon of the Far North culture. The bases of studying the Evenki language as a mother language were laid by the scholars doing their researches in the field of the Tungus people (V.A. Avrorina, G.M. Vasilevich, V.I. Tsinsius, M.G. Voskoboinikova, O.A. Konstantinova, V.D. Kolesnikova, E.P. Lebedeva, A.F. Boitsova and others who laid the theoretical bases for the development of teaching materials on the Evenki language).

In the 1980s, the problem of the return of the native language to general education process was raised again. The document mentions the fact that "after a long period and for objective reasons the issue of organization of teaching the Evenki language at the district schools was discussed by the executive committee of the Evenki district council of people's deputies in March 1968. As a result of the work with parents, teachers and the public and taking their opinions into account, the executive committee of the district council put forward a decision to teach the Evenk children of the district schools in Russian and to introduce the Evenki language as a subject. In the light of this decision the primary school teachers were retrained in August 1968". The students are offered an ABC-book to learn to read and write, and the teachers are offered "The Evenki primary school teacher's book". As for grades 4-8, it was necessary to move to an advanced level of knowledge of the native language since the study of it was included in the school programme in the form of a compulsory subject from 1974. The aim of the course was to attract the students to the language of their parents who were reindeer herders and hunters, "to learn the native language to become the teachers of the Native Language and Literature in primary and senior classes in the future. From 1971 to 1973 Z.N. Pikunova, a researcher of the sector of the schools of the North at 
the Research Institute of National Schools of the Ministry of Education, together with the district teachers and the author's team of the district department of public education had been doing experimental teaching of the Evenki language.

In the schools of the Evenki autonomous district such subject as the Native Language functioned in line with developmental education from grade 1 to grade 8 for 674 students in 4 secondary schools (the Tura secondary boarding school, the Baikit, Vanavara, Tutonchany secondary schools), 3 eight-year schools (Surinda, Poligus, Strelkovo) and 8 primary schools (Nidym, Uchami, Yukta, Kislokan, Chirinda, Ekonda, Kuyumba, Mutorai). On the one hand, in the course of the 1983-1984 educational experiment a time gap was revealed in transfer of the pedagogical experience of teaching the Evenki language. On the other hand, for ten years the school teachers had been testing new textbooks which were specifically compiled to teach the Evenk language and literature ("Evedy turen" and "Tanin dyarin kniga" textbooks). The teachers themselves considered teaching the mother (Evenk) language an experimental one, contributing to the search for creative new approaches in language learning. The teachers not only tested new textbooks, but also worked out recommendations for future editions of the textbooks in the Evenki language.

However, the manuscripts of these textbooks were not included in the publication plan: "Due to the lack of an editorial group the Krasnoyarsk book publishing house is unable to print these handbooks as well as children's, socio-political and fiction literature in the Evenki language" (p. 5). It is noted that despite the availability of the teaching staff from Igarka Pedagogical College and Leningrad State Pedagogical Institute named after A.I. Herzen "most of them do not speak their native language that lowers the effectiveness of teaching and knowledge assimilation by the students. This circumstance leads to the requirement that only those who know the Evenki language should be delegated to these educational institutions". The text further gives the proposals for the implementation of a set of measures such as publishing of textbooks for schools and preschool institutions, children's, fiction and political literature in the Evenki language from January 01, 1985; opening of the Department of the Evenki language in Krasnoyarsk Pedagogical College No. 2; publishing of a grammar textbook for grades 7-8 and of "The Teacher's Book" for grades 4-6; solving the problem of teaching the Evenki language teaching methods in Leningrad (nowadays - St. Petersburg) Pedagogical Institute named after A.I. Herzen; ordering the Leningrad branch of the Institute of Linguistics of the Academy of Sciences of the USSR to conduct an in-depth research of the Evenki spelling in linguistic aspect 
which is justified by the need to put the rules of the Evenki spelling in school practice in order.

The archival document "International education in the schools of the Evenki autonomous district" provides the information that 3.5 thousand children get their education at the Evenki schools in 1983-1984, 1000 of them are representatives of the peoples of the North and namely the dominant groups of the Evenks, Yakuts, Kets and other nationalities (Ukrainians, Belorussians, Kazakhs, Germans, Estonians, etc.). The idea of friendship of the peoples of a multinational country with the outstanding adults who are representatives of different nationalities as a unifying force becomes the concept of school education (for example, the meetings with reindeer herders during the open lessons on reindeer husbandry, the meetings with the authors of the textbooks in the Evenki language, artists). The holiday "The Birthday of Soviet Evenkia" and the native language competition become annual. As for teaching the Evenki language, it is given the role of an elective subject supported by extracurricular activities such as "The Week of the Russian and the Evenki languages".

"Materials on national schools and teaching of the native language, 1984" volume (25 sheets). The document contains the analysis of the national educational institutions' work in terms of ideological upbringing of students. The main idea is to intensify ideological and educational work in schools in the form of Komsomol and Pioneer movements. For example, it says that during the first month of studies, schools did not manage to follow the schedule of measures implementation ("Week of Revolutionary Glory", "Ideological Struggle at the Present Stage" conference, meetings devoted to the topic "Civil Rights and Duties of Soviet Schoolchildren" meetings of the shock workers and students, conversations in classes on fire safety measures and other measures). In schools there are few hobby groups, the coordination centre of the executive committee of the Ilimpiisk district council does not work. School graduates have an extremely low level of knowledge. In general, the whole text is permeated with the facts of continuous failures in the work of schools, the boarding school and the district as a whole. It concludes: "Self-management in schools does not work, students are not focused on immediate tasks and prospects".

Another document - a reference on the work of the public education institutions of the district in the 1985-1986 school year, an entirely different, improved situation in the northern schools of the Krasnoyarsk Krai is demonstrated: a new school and three kindergartens had been built, some schools had been reorganized into 8-year schools, school buildings had been repaired, the qualitative composition of teaching staff had 
been improved, "in the schools of the district, work continues to improve the teaching of the Russian and the native languages in grades 9-10."

However, that year there was a lack of job places for school graduates at fur farms, dairy farms, in field farming and reindeer breeding teams. The issue of remuneration of mentor work was not solved. The results of checking the knowledge of students showed that there were serious shortcomings in the cognitive activity of students, low knowledge level in basic subjects, which led to "the failure to plan school graduates' further studies at higher educational institutions and vocational schools, especially in natural science" (p. 2). Teachers were blamed in serious shortcomings of the work on the implementation of the school reform, they were instructed to reorganize their work according to the demands of the 27th Congress of the CPSU and persistently seek to radically improve the quality of education and upbringing of schoolchildren in the spirit of devotion to the socialist homeland and proletarian internationalism.

"Information on measures to improve the activities of public education institutions in 1986-1990 sent to the district committee of CPSU, 1986" volume (5 sheets). This document manifests the issue of the prospects for the revival of the national school and the need to develop a model of the national school (Evenki, Yakut) set by the specialist of the district educational authority A.T. Lapuko. It is about the revival of the practical introduction of the experience of teaching the native language, national and applied crafts, artistic and aesthetic subjects, practical experience in the basics of fur farming, renting reindeer pastures for observation. It is noted that the employees of the district educational authority and the parents of the pupils do not pay due attention to school. School is considered a secondary link in education, it is not respected. It is necessary to draw their attention to the problems of upbringing and education and, as a proposal, "to introduce subjects with a national and religious component, to improve pupils' learning of the native language, to consolidate supervision over the native language in the district by a native language inspector, to determine a national-religious component for their district."

The 2000s. "Annual statistical report of the Education Department of the Evenki Autonomous District Administration "Data on the distribution of schools and pupils by the language of instruction and learning of the native (not Russian) language, 2003" volume (3 sheets). This is quite a brief summary document, which contains the table with the information about schools, which teach the native (not Russian) language as a subject: total 24 (Russian) schools, 21 of them teach native 
languages: in Ket (14 people in 1 grade), Evenki (19 schools from 1 to 4 grades) and Yakut (1 school in 1, 2 and 4 grades).

\section{Conclusion}

The 1930s is the period when the Concept of cultural construction was launched at the territory of the Far North. As in 1932 national districts were formed, special attention of the state and regional authorities was focused on practical introduction of national languages and literacy of the peoples of the North. The documents contain the information about the scale of the programme of cultural construction: it was necessary to create a net of exemplary national schools with state support, to hire highly qualified teachers (fluent in northern languages), to develop northern programmes of school education and mass enlightenment, to publish school books in native languages, to provide methodological development on the part of Northern research centres. Thus, it was planned to cover all illiterate people, to understand the unique features of the culture of each northern nationality and to involve it into the culture of the dominant society. Culture service in native languages becomes a practice of cultural adaptation of adults and children of indigenous population to the industrial culture. For this purpose, the programme of education includes a plan of step-by-step educational progress both in the field of public education and in relation to national northern cultures.

The 1940s: large northern regions are monitored for illiterate population, labourintensive work is started in order to eliminate illiteracy among the population and to promote general education. In the district schools there is a strict record of the number of students, their national composition, and timely arrival at the beginning of the school year. As for the study of native languages, education is conducted in the native and Russian languages in all schools without exception. Directors of the district schools write about difficulties in the process of school education: long cold winters do not allow to provide proper assistance to schools, there are not enough textbooks and manuals, there are violations in the educational discipline of indigenous children, etc.

The 1950s: the programme of eliminating illiteracy is well under way. For its implementation in the northern regions, directives on methodical work are assigned, Komsomols arrive in the places of compact residing of reindeer and hunting teams for carrying out a general educational programme, reading rooms are created, the local elite is attracted to the educational programme, special attention is paid to the study of native languages in schools (genre literature appears for each grade, a programme for native literature for grades 4-6). 
The 1960s: according to archival documents, in this decade significant work was under way to create detailed curricula for each grade of district schools, indicating the types of work with students, lists of literary texts for reading.

The 1970s: the main fact outlined in the first five years basically was that despite enormous efforts on the part of national and school education, there were serious problems with attracting adults to get education, to inspire young people for application to technical schools and universities, to perform ubiquitous transition to secondary (seven-year) school education. In connection with the existing problems, since 1975 active assistance comes from the northern schools' sector of the National Research Institute of National Schools: the staff members analyze the written works of pupils sent from district schools to study the level of knowledge and skills in Russian and native languages of primary school pupils of the indigenous nationalities of the North; textbooks and reviews to their publication are written. The result of the enormous work being done is the publication of a comprehensive textbook on the Russian language for the pre-school and first grades of schools with native and Russian languages of instruction. The textbooks are sent to the district schools.

The 1980s: teaching and learning in the native and Russian language is conducted in all district schools, the composition of students is mixed. However, the problem of studying the native language at an advanced level is revealed (grades 4-8). The study of the Evenki language becomes a school subject, a methodical manual for teachers "Book for the teacher of the Evenki elementary school" is published. Thus, the study of the language becomes experimental, the subject of enlightenment and familiarization with the northern culture (stories about everyday life, fishing, acquaintance with fairy tales, literary works, etc.). In the late 1980s the issue of the revival of the Evenki language and the introduction of practical experience in teaching the native language is already seriously raised.

\section{References}

Alpatov, V.M. (2000). 150 iazykov i politika. 1917-2000. Sotsiolingvisticheskie problem SSSR $i$ postsovetskogo prostranstva [150 languages and politics. 19172000. Socio-linguistic problems of the USSR and the post-Soviet areas]. Moscow, $224 \mathrm{p}$.

Al'kor (Koshkin), Ia.P. (1932). Voprosy sozdaniia i razvitiia natsional'noliteraturnykh iazykov i pis'mennostei narodov Severa [Issues of creation and development of the national and literature languages and written languages of the 
peoples of the North]. In Materialy I Vserossiiskoi konferentsii po razvitiiu iazykov i pis'mennosti narodov Severa [Materials of the $1^{\text {st }}$ All-Russian Conference on the development of languages and written languages of the peoples of the North]. Moscow, Leningrad, 39-64.

Al'kor, Ia.P. (1934). Novaia pis'mennost' narodov Severa [New written languages of the peoples of the North]. In Alfavit Oktiabria [October's ABC], 81-89.

Al'kor, Ia.P. (1930). Proekt alfavita evenkiiskogo (tungusskogo) iazyka [Draft ABC of the Evenki (Tungus) language]. In Materialy po izucheniiu Iakutskoi Avtonomsnoi Sotsialistichekoi respubliki [Materials on the study of the Yakut Autonomous Socialist Republic]. Leningrad, (33), 14.

Anderson, D.G. (1991). Turning hunters into herders: A critical examination of Soviet development policy among the Evenki of southeastern Siberia. In Arctic, 44(1), $12-22$.

Anderson, D.G. (1998). Property as a way of knowing on Evenki lands in Arctic Siberia. In Property relations: Renewing the anthropological tradition, 64-84.

Antoshin, K.F. (1987). Vechno zhivye istoki (O folklore i molodoi sovetskoi literature narodov i narodnostei Sibiri, Krainego Severa i Dal'nego Vostoka) [Permanently alive sources (On the folklore and young Soviet literature of the peoples and nations of Siberia, Far North and Far East)]. Krasnoyarsk: Publishing house of Krasnoyarsk State University.

Aref'ev, A.L. (2015). O iazykakh korennykh malochislennykh narodov Rossii [About the languages of indigenous small-numbered peoples of Russia]. In Sotsiologicheskie issledovaniia [Sociological studies], 8 (376), 75-84.

Artemenko, O.I. (2007). Kul'tura i obrazovanie korennykh malochislennykh narodov Severa [Culture and education of indigenous small-numbered peoples of the North]. Moscow, ANO INPO, $191 \mathrm{p}$.

Arutiunov, S.A. (1987). Rol' i mesto iazyka v etnokul'turnom razvitii obshchestva [Role and place of the language in the ethno-cultural development of the society]. In Etnicheskie protsessy $v$ sovremennom mire [Ethnic processes in the modern world]. Moscow, Nauka, 44-67.

Akhmetova, A.V. (2014). Evoliutsiia sistemy vospitaniia i obrazovaniia korennykh malochislennykh narodov Dal'nego Vostoka v 1960-e nachale 1990-kh gg. [Evolution of the system of upbringing and education of indigenous small-numbered peoples of the Far East in the 1960s - beginning of the 1990s]. In Dokument. Arkhiv. Istoriia. Sovremennost' [Document. Archive. History. Modernity]. (14), 112-121. 
Bazanov, A.G., Kazanskii, N.G. (1939). Shkola na Krainem Severe [School in the Far North]. Leningrad, Uchpedgiz, 205 p.

Baldanov, S.Zh. (2004). Sibir' - edinoe fol'klorno-literaturnoe polietnicheskoe prostranstvo [Siberia: unified folklore and literature polyethnic space]. Yakutsk, 155-162.

Beloliubskaia, V.G. (2014). Iazyki korennykh narodov Severa: istoriia i sovremennost [Languages of the indigenous peoples of the North: history and modern time]. In Vysshee obrazovanie v Rossii [High education in Russia], (5), 110-115.

Borgoiakova, T.G. (2001). Minoritarnye iazyki: problemy sokhraneniia i razvitiia [Minority languages: problems of preservation and development]. Abakan, Publishing House of N.F. Katanov's Khakass State University.

Bulatova, N.Ia. (2008). Nekotorye problem perevoda Biblii na evenkiiskii iazyk [Some challenges of translating Bible into the Evenki language]. In Perevod Biblii kak factor sokhraneniia i razvitiia iazykov RF i SNG.24-26 sentiabria 2008 g. Materialy konferentsii [Bible translation as a factor o preservation and development of languages of the Russian Federation and the CIS. 24-26 of September 2008. Conference materials]. Moscow, 32-36.

Bulatova, N.Ia. (1989). Obychenie rodnomu iazyku vo 2 klasse [Teaching the native language in the $2^{\text {nd }}$ grade]. In Kniga dlia uchitelia evenkkiiskoi nachalnoi shkoly [Teacher's book of the Evenki primary school]. Leningrad, 71-103.

Bulatova, N.Ia. (2001). Uchebnaia kniga kak sredstvo sokhraneniia i razvitiia rodnogo iazyka [Student's book as a means of preservation and development of the native language]. Saint-Petersburg, 24-25.

Bulatova, N.Ia. (2003). Uchebniki novogo pokoleniia dlia natsional'nykh shkol Severa [Student's books of new generation for national schools of the North]. In Materialy Mezhdunarodnoi nauchno-prakticheskoikonferentsii "Sokhranenie irazvitie rodnykh iazykov i kul'tury korennykh malochislennykh narodov Severa v Taimyrskom (Dolgano-Nenetskom) avtonomnom okruge” [Materials of the International Scientific and Practical conference "Preservation and development of native languages and cultures of the indigenous small-numbered peoples of the North in the Taymyr (Dolgano-Nenets) autonomous district”']. Dudinka, 27-30.

Bulatova, N.Ia. (2002). Evenkiiskii iazyk v tablitsakh: Uchebnoe posobie dlia evenkiiskikh shkol, pedagogicheskikh kolledzhei, vuzov [The Evenki language in tables: student's book for the Evenki schools, pedagogical colleges and higher educational institutions]. Saint-Petersburg, 64 p. 
Chumak, E.G. (2008). Osnovnye meropriiatiia gosudarstvennoi obrazovatel'noi politiki v otnoshenii korennogo naseleniia Severa v 20-50-e gg. XX v. [The main activities of the state educational policy in relation to the indigenous population of the North in the 20-50s of the $20^{\text {th }}$ century]. In Vestnik arkheologii, antropologii $i$ etnografii [Bulletin of archeology, anthropology and ethnography], (8), 109-114.

Dolgikh, B.O., Chard, C.S. (1972). The formation of the modern peoples of the Soviet north. In Arctic Anthropology, 17-26.

Ermolova, N.A. (2000). Glafira Makar'evna Vasilevich i sovremennye problem tungusovedeniia [Glafira Makar'evna Vasilevich and modern problems of the Tungus studies]. In 285 let Peterburgskoi Kunstkamere [285 th anniversary of Saint-Petersburg Kuntskamera]. Saint-Petersburg, 205-212.

Ermolova, N.V. (2003). Tungusoved Glafira Makar'evna Vasilevich [Tungus culture specialist Glafira Makar'evna Vasilevich]. In Repressirovannye etnografy [Ethnographers under political excesses]. Moscow, (2), 10-46.

Gashilova, L.B. \& Nabok, A.A. (2012). Etnoregional'noe obrazovanie na Severe: puti razvitiia $\mathrm{i}$ modernizatsii [Ethno-regional education in the North: ways of development and modernization]. In Sovremennoe sostoianie i puti razvitiia korennykh malochislennykh narodov Severa, Sibiri i Dal'nego Vostoka [Modern state and ways of development of indigenous small-numbered peoples of the North, Siberia and the Far East]. Moscow, Russian Federation Council, 191 p.

Golovin, A.F. (2010). Kochevaia shkola kak sotsial'no-pedagogicheskaia osnova formirovaniia sistemy obrazovaniia na Krainem Severe: puti stanovleniia i problemy razvitiia [Nomadic school as a socio-pedagogical basis to form the system of education in the Far North: ways of establishment and challenges of development]. In Sibirskii pedagogicheskii zhurnal [Siberian pedagogical journal]. (1), 252-271.

Gorelikov, A.I. (2015) Natsional'naia politika v otnoshenii korennykh malochislennykh narodov Dal'nego Vostoka v poslevoennyi period (1945-1950kh gg.) [National policy in relation to the indigenous small-numbered peoples of the Far East after the WWII (1945 - first half of the 1950s)]. In Teoriia i praktika obshchestvennogo razvitiia [Theory and practice of the public development]. (7), 136-138.

Gorodenko, D.V. (2013). Obrazovanie narodov Severa kak factor razvitiia polikul'turnogo prostranstva regiona (na primere Khanty-Mansiiskogo avtonomnogo okruga Iugry) [Education of the peoples of the North as a factor of development of the multicultural space of the region (on the example of the Khanty-Mansiisk Autonomous 
District of Yurga)]. Nizhnevartovsk, Publishing House of Nizhnevartovsk University for the Humanities, $143 \mathrm{p}$.

Gortsevskaia, V.A. (1959). Ocherk istorii izucheniia tunguso-manchzhurskikh iazykov [Historical note on the studies of the Tungus-Manchurian languages]. Leningrad, $78 \mathrm{p}$.

Gortsevskii, A.A. (1938). Nekotorye voprosy fonetiki evenkiiskogo iazyka v sviazi s obucheniem evenkov russkomu iazyku [Some phonetic aspects of the Evenki language connected with teaching the Evenks Russian]. In Sovetskii sever [Soviet North]. Leningrad, 1.

Grenoble, L.A., Whaley, L.J. (1999). Language Policy and the Loss of Tungusic Languages. In Language \& Communication, 19(4), 373-386.

Ivanova, E.V. (2008). Sotsio-etnicheskie problemy istorii evenkiiskoi literatury [Socio-ethnic problems of the history of the Evenk literature]. Thesis for Candidate's Degree in Philology, Saint-Petersburg.

Ivanova, E.V. (2004). Etnicheskoe kak put' k obshcherossiiskomu (po stranitsam evenkiiskoi literatury kontsa $\mathrm{XX}$ veka) [The ethnic as a way to the all-Russian (following the Evenki literature of the end of the 20 $0^{\text {th }}$ century)]. In Real'nost' etnosa. Obrazovanie $i$ natsional'naia ideia. Materialy VI Mezhdunarodnoi nauchnoprakticheskoi konferentsii. [Reality of the ethnic group. Education and national idea. Materials of the $6^{\text {th }}$ International scientific and practical conference], 425-427.

Kalenchuk, E.A. (2015). Istoriia izucheniia literaturnogo fol'klora u korennykh i malochislennykh narodov Severa, Sibiri i Dal'nego Vostoka [History of studying the literature folklore of the indigenous small-numbered peoples of the North, Siberia and the Far East]. In Istoriia [History], 62-66.

Kalenchuk, E.A.\&Banshchikova, A.R. (2015). Istoriia izucheniia literaturnogo fol'klora u korennykh i malochislennykh narodov Severa, Sibiri i Dal'nego Vostoka [History of studying the literature folklore of the indigenous small-numbered peoples of the North, Siberia and the Far East]. In Problemy sotsial'no-ekonomicheskogo razvitiia Sibiri [Problems of socio-economic development of Siberia]. 3 (21), 62-66.

Khazankovich, Iu.G. (2009), Bilingvizm kak protsess mezhkul'turnoi kommunikatsii i ego funktsionirovanie v proze malochislennykh narodov Severa i Dal'nego Vostoka [Bilingualism as a process of intercultural communication and its functioning in the prose of small-numbered peoples of the North and the Far East]. In Vestnik Severo-vostochnogo federalnogo universiteta im. M.K. Ammosova [Bulletin of the North-eastern Federal University named after M.K. Ammosov], 6 (1), 101-106. 
Khazankovich, Iu.G. (2014). Kul'tura i literature malochislennykh narodov Arktiki: "Vlast' traditsii" [Culture and literature of small-numbered peoples of the Arctic: "Power of tradition"]. In Vestnik Severo-vostochnogo federalnogo universiteta im. M.K. Ammosova [Bulletin of the North-eastern Federal University named after M.K. Ammosov]. 11 (1), 142-149.

Khazankovich, Iu.G. (2009). Literatura i knizhnaia kul'tura evenkov: k istokam zarozhdeniia [Literature and book culture of the Evenks: to the origins]. In Vestnik Zabaikal'skigi universiteta [Bulletin of the Baikal Regional University]. (2), 176-181.

Khazankovich, Iu. G. (2009). Proza malochislennykh narodov Sibiri, Severa i Dal'nego Vostoka v kritike 1970-1990-kh gg. [Prose of small-numbered peoples of Siberia, the North and the Far East in the critics of the 1970-1990s]. In Vestnik Chitinskogo gosudarstvennogo universiteta [Bulletin of the Chita State University]. 3 (54),185-190.

Khazankovich, Iu.G. (2007). Fol'klor i literatury narodov Severa: osobennosti vzaimodeistviia [Folklore and literature of the peoples of the North: peculiarities of interaction]. In Gumanitarnye nauki v Sibiri: nauchnyi zhurnal [Humanities in the Siberia: scientific journal]. Novosibirsk, SBRAS, (4), 85-89.

Khazankovich, Iu.G. (2009). Evenkiiskaia literature: problem periodizatsii [The Evenk literature: problems of periodization]. In Izvestiia Rossiiskogo gosudarstvennogo pedagogicheskogo universiteta im. A.I. Gertsena [News of Herzen University], (108), 99-109.

Khazankovich, Iu. G. (2009). Puti i puty kritiki: O sovremennom sostoianii izucheniia literatur malochislennykh narodov Severa i Sibiri [Ways and challenges of critics: on the modern state of studies of literature of small-numbered peoples of the North and Siberia]. In Sibirskii filologicheskii zhurnal [Siberian philological journal], (3), 78-83.

Kolesnik, M.A. (2014). Obzor izucheniia fol'klora korennykh narodov Severa [Review of studies of the folklore of the indigenous peoples of the North]. In Litera, (3), 39-59. Available at: http://e-notabene.ru/fl/article_13998.html

Konstantinova, O.A. (1964). Evenkiiskii iazyk [The Evenki language]. Moscow, Leningrad, $272 \mathrm{p}$.

Konstantinova, O.A. (1968). Evenkiiskii iazyk [The Evenki language]. In Iazyki narodov SSSR - T.V. Mongol'skie, tunguso-manchzhurskie i paleoaziatskie iazyki [Languages of the USSR nations - T.V. Mongolic, Tungus-Manchurian and PaleoSiberian languages]. Leningrad. 
Koptseva, N.P. (2014). K voprosu o gosudarstvennoi politike v oblasti sokhraneniia iazykov korennykh malochislennykh narodov severa [On the issue of the state policy in relation of preserving languages of indigenous small-numbered peoples of the North]. In Arktika i Sever [The Arctic and the North], (16), 34-40.

Koptseva, N.P., Khizhniakova, A.N. \& Reznikova, K.V. (2017). K voprosu o kontseptakh iazykov korennykh narodov Krasnoiarskogo kraia [On the issue of the concepts of the languages of indigenous peoples of the Krasnoyarsk Krai]. In Severnye arkhivy $i$ ekspeditsii [Northern archives and expeditions]. (1), 6-22.

Koptseva, N.P., Kirko, V.I. (2014). Modern specificity of legal regulation of Cultural Development of the Indigenous Peoples of the Arctic Siberia (the Altay Region, the Zabaikailsky Region, Republic of Buryatia, Russia). In Life Science Journal, 11(9), 314-319.

Koptseva, N.P., Kirko, V.I. (2015). The impact of global transformations on the processes of regional and ethnic identity of indigenous peoples Siberian Arctic. In Mediterranean Journal of Social Sciences, 6(3 S5), 217-223.

Koptseva, N.P., Kirko, V.I. (2014). The information basis for formation of positive ethnic identities in the process of acculturation of indigenous peoples of the Arctic Siberia (Krasnoyarsk, Russia). In Life Sci. J., 11(8), 479-483.

Kudashkin, V.A. (2013). Protsess akkul'turatsii u korennykh malochislennykh narodov Vostochnoi Sibiri v usloviiakh sovetskoi sistemy v 1920-1980-e gg. [The process of cultural assimilation among indigenous small-numbered peoples of the Eastern Siberia in the conditions of the Soviet system in 1920s-1980s]. In Istoricheskie, filosofskie, politicheskie i iuridicheskie nauki, kul'turologiia $i$ iskusstvovedenie. Voprosy teorii $i$ praktiki [Historical, philosophic, political and judicial sciences, cultural and art studies]. 2 (3), 102-105.

Kudashkin, V.A. (2013). Sokhranenie iazykovoi pamiati u korennykh narodov Vostochnoi Sibiri vo vtoroi polovine XX v. [Preservation of the language memory among the indigenous peoples of the Eastern Siberia in the second half of the $20^{\text {th }}$ century]. In Problemy sotsial'no-ekonomicheskogo razvitiia Sibiri [Problems of the socio-economic development of Siberia]. (4), 58-60.

Kudashkin, V.A., Ivanchenko, E.V. (2015). Izuchenie rodnykh iazykov korennykh malochislennykh narodov Severa i Sibiri v sisteme obrazovaniia v 1985-2011 gg. [Studying the native languages of the indigenous small-numbered peoples of the North and Siberia in the system of education in 1985-2011]. In Problemy sotsial'noekonomicheskogo razvitiia Sibiri [Problems of the socio-economic development of Siberia]. (3), 67-71. 
Lagunova, O.K. (2011). Nauchnye versii literaturnogo tvorchestva korennykh malochislennykh narodov Severa Zapadnoi Sibiri [Scientific versions of literature creativity of indigenous small-numbered peoples of the north of the Western Siberia]. In Vestnik Tiumenskogo gosudarstvennogo universiteta [Tyumen State University bulletin], (1), 60-68.

Lagunova, O.K. (2010). Nauchnye versii literaturnogo tvorchestva korennykh malochislennykh narodov Severa Zapadnoi Sibiri [Scientific versions of literature creativity of indigenous small-numbered peoples of the north of the Western Siberia]. In Ot teksta k tekstu [From text to text], (9), 143-148.

Lapuko, A.T. (2008). Evenkiiskiyi iazyk: vospitanie i obuchenie v detskom sadu, shkole i etnoekologicheskikh stoibishchakh. Programma dlia obucheniia vospitatelei DOU, uchitelei evenkiiskogo iazyka nachal'nykh i obshcheobrazovatel'nykh shkol, vospitatelei etnoekologicheskikh stoibishch [The Evenki language: education and training in kindergarten, school and ethno-ecological camps. The programme for training of the pre-university educators, Evenk teachers of primary and secondary schools, educators of ethno-ecological camps]. Tura, 9 p.

Leonard, W.R., Katzmarzyk, P.T., Comuzzie, A.G., Crawford, M.H., Sukernik, R.I. (1994). Growth and nutritional status of the Evenki reindeer herders of Siberia. In American journal of human biology, 6(3), 339-350.

Libakova, N.M., Sitnikova, A.A., Sertakova, E.A., Kolesnik, M.A., Ilbeykina, M.I. (2014). Modern practices of regional and ethnic identity of the Yakuts (North Asia, Russia). In Life Sci. J., 11(12), 133-140.

Lizunova, I.V. \& Bulgakova, E.V. (2013). Izdanie knig dlia detei v Sibiri i na Dal'nem Vostoke (1990-e gg.) [Publishing children books in Siberia and the Far East (1990-e gg.). In Gumanitarnye nauki v Sibiri [The humanities in Siberia], (3), 66-70.

Literatura narodov Severa [Literature of the peoples of the North] (2002). SaintPetersburg, Publishing house of Herzen University].

Literatura narodov Severa, Sibiri i Dal'nego Vostoka: Sovremennye podkhody v teorii i metodike issledovaniia i prepodavaniia [Literature od the peoples of the North, Siberia and the Far East: Modern approaches in the theory and methods of studies and teaching] (2007). In Rel'nost' etnosa [Reality of the ethnic group], 236-298.

Mamontova, N.A. (2014). What Language Do Real Evenki Speak? Discussions Surrounding the Nomad Preschool. In Anthropology \& Archeology of Eurasia, 52(4), 37-75.

Marchenko, O.N. (2014). Kul'turovedcheskii i etnokul'turnyi podkhody k izucheniiu fol'klora narodov Sibiri [Cultural and ethno-cultural approaches to studying 
folklore of the peoples of Siberia]. In Russkii iazyk v natisionl'noi shkole [The Russian language in the national school]. (1), 14-25.

Matis, V.I. (1996). Sovremennye podkhody k natsional'nomu obrazovaniiu [Modern approaches to national education]. In Obrazovanie v Sibiri [Education in Siberia]. (1), 69-80.

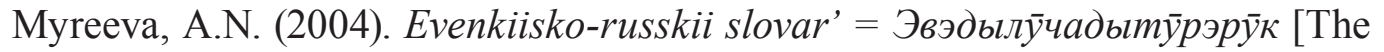
Evenki-Russian dictionary], Novosibirsk, 798 p.

Myreeva, A.N. (1990). Evenkiiskie geroicheskie skazaniia [The Evenk heroic tales]. Novosibisk, Nauka, Sibirskoe otdelenie [Siberian branch].

Nepomniashchikh, N.A. (2014). Chelovek na perekrestke kul'tur: evenkiiskaia literatura v sovremennom mire [Man at the crossroads of cultures: the Evenk literature in the modern world]. In Antropologicheskie sdvigi perelomnykh epokh $i$ ikh otrazhenie $v$ literature: sb. nauchnykh statei $v 2$ chastiakh [Anthropological shifts of the turning epochs and their reflection in the literature: collection of scientific articles in 2 parts], 45-51.

Nepomniashchikh, N.A. (2014). Evenkiiskaia literatura: spetsifika genezisa i bytovaniia, tipicheskie siuzhety i motivy [The Evenk literature: the specific features of genesis and existence, typical plots and motifs]. In Sibirskii filologicheskii zhurnal [Siberian philological journal], (4), 75-82.

Ogryzko, V.V. (2013). Litsa i liki: literature malochislennykh narodov Severa $i$ Dal'nego Vostoka [Faces: literature of small-numbered peoples of the North and the Far East]. Moscow, Literaturnaia Rossiia [Literature Russia].

Ogryzko, V.V. (1998). Pisateli i literatory malochislennykh narodov Severa $i$ Dal'nego Vostoka: biobibliograficheskii spravochnik [Writers and authors of smallnumbered peoples of the North and the Far East: biobibliographic reference]. Moscow, Literaturnaia Rossiia [Literature Russia].

Petrov, A.A. (2011). Problemy sokhraneniia i razvitiia iazykov i literature malochislennykh narodov Severa [Problems of preservation and development of languages and literatures of small-numbered peoples of the North]. In Universum: Vestnik Gertsenovskogo universiteta [Universum: Herzen University bulletin], (11), 37-40.

Pikunova, Z.N. (1999). Kartinnyi slovar' evenkiiskogo iazyka [Picture dictionary of the Evenki language]. Saint-Petersburg, $191 \mathrm{p}$.

Pikunova, Z.N. (1992). Kniga dlia chteniia v 8-9 klassakh evenkiiskikh shkol [Book for reading in 8-9 grades of the Evenk schools]. Saint-Petersburg, 191 p. 
Pikunova, Z.N. (1979). Sbornik diktantov dlia nachal'nykh klassov evenkiiskikh shkol: posobie dlia uchitelia [Collection of dictations for primary school of the Evenk schools: Teacher's book]. Leningrad, 190 p.

Polivanov, E.D. (1927). Rodnoi iazyk v natsional'noi shkole [The native language in the national school]. In Voprosy natsional'nogo partprosveshcheniia [Issues of national party enlightenment]. Moscow, 114.

Popova, N.S. (1934). Uchebnik arifmetiki dlia 1 klassa nachal'noi shkoly. Perevod G.M. Vasilevich. [Student's book of arithmetic for the $1^{\text {st }}$ grade in the primary school. Translation by G.M. Vasilevich]. Leningrad, 17 p.

Popova, N.S. (1934). Uchebnik arifmetiki dlia 2 klassa nachal'noi shkoly. Perevod G.M. Vasilevich. [Student's book of arithmetic for the $2^{\text {nd }}$ grade in the primary school. Translation by G.M. Vasilevich]. Leningrad, 30 p.

Popova, N.S. (1934). Uchebnik arifmetiki. 1 god obucheniia. Kontrperevod s evenkiiskogo iazyka G.M. Vasilevich. [Student's book of arithmetic. $1^{\text {st }}$ year of studies. Retranslation from the Evenki language by G.M. Vasilevich]. Leningrad, 18 p.

Poshataeva, A.V. (1988). Literatury narodov Severa: (Istoki, Stanovlenie. Razvitie) [Literatures of the peoples of the North: (Origin, establishment and development)]. Moscow, Nauka.

Prosveshchenie na Sovetskom Krainem Severe [Enlightenment in the Soviet Far North] (1957). Leningrad, 81 p.

Reznikova, K.V., Zamaraeva, J.S., Kistova, A.V., Pimenova, N.N. (2014). The current state of traditional socio-cultural practices of indigenous peoples of the North (on the example of cultures of Selkups, Nenets and Essey Yakuts). In Life Sci. J., 11(12), $126-132$.

Romanova, A.V., Boitsova, A.F. (1953). Uchebnik po evenkiiskomu iazyku dlia podgotovitel'nogo klassa [Student's book on the Evenki language for the pre-school]. Moscow, Leningrad.

Romanova, A.V., Myreeva, A.N. (1968). Dialektologicheskii slovar' evenkiiskogo iazyka. Dialektologicheskie materialy po govoram evenkov Iakutskoi ASSR. Vyp. III. [Dialectic dictionary of the Evenki language. Dialectic materials on the languages of the Evenks in the Yakut ASSR. $3^{\text {rd }}$ Issue]. Leningrad, 215 p.

Safonova, T., Sántha, I. (2011). Mapping Evenki land: The study of mobility patterns in Eastern Siberia. In Folklore, 49, 71-96.

Sakova, R.T. (1985). Fol'klor i literature narodov Sibiri [Folklore and literature of the peoples of Siberia]. Krasnoyarsk. 
Sangi, V.M. (1989). Antologiia fol'klora narodnostei Sibiri, Severa i Dal'nego Vostoka [Anthology of folklore of the nations of Siberia, the North and the Far East], $471 \mathrm{p}$.

Seredkina, N.N., Smolina, M.G. \& Kistova, A.V. (2017). Vliianie eposa na skazki korennykh narodov Severa i Sibiri [ Influence of the epos on the fairy tales of indigenous peoples of the North and Siberia]. In Sibirskii antropologicheskii zhurnal [Siberian anthropological journal]. (1), 62-73.

Shprygov, Iu. M.(2005). Stanovlenie irazvitieliteraturykorennykhmalochiclennykh narodov Severo-Vostoka (kak dukhovno-intellektual'nyi protsess) [Establishment and development of literature of the indigenous small-numbered peoples of the North-East (as a spiritual and intellectual process)]. In Intellektual'nye resursy Severo-Vostoka Rossii [Intellectual resources of the North-East of Russia], 272-274.

Shchapova, D.A. Pochuvstvovali sebia evenkami [We felt as the Evenks]. Available at: http://epc.osiktakan.ru/ethnos/Izuch_evenk_yazyk/Izuch_evenk_yazyk.html

Simonova, V.V. (2012). The Evenki Memorial Tree and Trail: Negotiating with a Memorial Regime in the North Baikal, Siberia. In Journal of Ethnology and Folkloristics, 6(1), 49-69.

Sitnikova, A.A. (2015). Korennoe obrazovanie: aktual'noe sostoianie i problemy [National education: current state and problems]. In Pedagogika i prosveshchenie [Pedagogics and enlightenment]. (3), 300. DOI: 10.7256/2306-434X.2015.3.17048.

Ssorin-Chaikov, N. (2001). Evenki shamanistic practices in Soviet present and ethnographic present perfect. In Anthropology of Consciousness, 12(1), 1-18.

Sturov, K.V. (1978). Problemy osushchestvleniia vseobshchego obiazatel'nogo srednego obrazovaniia $v$ usloviiakh Krainego Severa (na materiale Eniseiskogo Severa) [Challenges of general obligatory comprehensive education in the conditions of the Far North (on the materials of the Yeniseisk North)]. Moscow, 13 p.

Troiak, I.S. (2014). Vypusk detskoi literatury dlia korennykh malochislennykh narodov Dal'nego Vostoka v kontse XX - nachale XXI v. [Publishing of children literature for indigenous small-numbered peoples of th Far East in the end of the $20^{\text {th }}-$ beginning of the $21^{\text {st }}$ century]. In Trudy GPNTB SO RAN [Works of the State Public Scientific and Technical Library of the Siberian Branch of the Russian Academy of Science]. Publishing House of the State Public Scientific and Technical Library of the Siberian Branch of the Russian Academy of Science, (6).

Tsintsius, V. I. (1949) Sravnitel'naia fonetika tunguso-manchzhurskikh iazykov [Comparative phonetics of the Tungus-Manchurian languages]. Leningrad, $344 \mathrm{p}$. 
Tsintsius, V.I. (1975, 1977). Sravnitel'nyi slovar' tunguso-man'chzhurskikh iazykov: Materialy $k$ etimologicheskomu slovariu [Comparative dictionary of the TungusManchurian languages: Materials to the etymological dictionary]. Leningrad.

Tsintsius, V.I., Gortsevskaia, V.A. (1959). Izuchenie tunguso-man'chzhurskikh iazykov Sovetskogo Soiuza za 40 let [Study of the Tungus-Manchurian languages of the Soviet Union for 40 years]. In Uchenye zapiski LGPI im. A.I. Gertsena [Herzen University notes], 169, 5-47.

Tsintsius, V.I. (1972). Khronologicheskii perechen' rabot G.M. Vasilevich i literatura o nei (1926-1971) [The chronological list of works by G.M. Vasilevich and literature about her (1926-1971)]. In Voprosy iazykov i fol'klora narodnostei Severa [Issues of languages and folklore of the peoples of the North]. Yakutsk.

Vasilevich. G.M. - krupneishii sovetskii tungusoved. Sbornik statei k 70-letiiu so dnia rozhdeniia [Vasilevich G.M.: the greatest Soviet tungus studies specialist. Collection of articles published in the view of the $70^{\text {th }}$ birthday]. Yakutsk, $48 \mathrm{p}$.

Vasilevich, G.M. (1960). K voprosu o klassifiktsii tungusomanchzhurskikh iazykov [On the issue of classification of Tungus-Manchu languages]. In Voprosy iazykoznaniia [Issues of language studies], (2), 43-49.

Vasilevich, G.M. (1951). K voprosu o nachale stanovleniia tungusskikh iazykov [On the issue of the beginning of development of the Tungus languages]. In Soveshchanie po metodologii etnogeneticheskikh issledovanii 1951 g., Tezisy dokladov $i$ vystuplenii [Meeting devoted to the methods of ethnic and genetic studies in 1951, Abstracts of speeches]. Moscow, 2-4.

Vasilevich, G.M. (1931). Nachal'naia tungusskaia kniga [Primary Tungus book]. Moscow, 128 p.

Vasilevich, G.M. (1940). Ocherki grammatiki evenkiiskogo (tungusskogo) iazyka [Grammatical issues of the Evenki (Tungus) language]. Leningrad, 196 p.

Vasilevich, G.M. (1948). Ocherki dialektov evenkiiskogo (tungusskogo) iazyka [Dialectical issues of the Evenki (Tungus) language]. Leningrad, 352 p.

Vasilevich, G.M. (1929). Pervaia kniga dlia chteniia na tungusskom iazyke. Steklograf [The first book for reading in the Tungus language. Collotype press]. Leningrad, $28 \mathrm{p}$.

Vasilevich, G.M. (1958). Perevodcheskaia rabota na iazykakh narodov Severa za gody Sovetskoi vlasti [Translation work in the languages of the peoples of the North during the Soviet period]. In V pomoshch uchiteliu shkol Krainego Severa [Assistance materials for school teachers in the Far North]. Leningrad, (8), 228-234. 
Vasilevich, G.M. (1969). Evenki. Istoriko-etnograficheskie ocherki (XVII-XX vv.) [The Evenks. Historical and ethnographic notes $\left(18^{\text {th }}-20^{\text {th }}\right.$ centuries $\left.)\right]$. Leningrad, $304 \mathrm{p}$.

Vasilevich, G.M. (1951). Evenkiiskii iazyk. Uchebnik dlia 2 klassa evenkiiskoi nachal'noi shkoly [The Evenki language. Student's book for the $2^{\text {nd }}$ grade of the Evenk primary school]. Leningrad, $120 \mathrm{p}$.

Vasilevich, G.M. (1948). Ocherki dialektov evenkiiskogo (tungusskogo) iazyka [Dialectic issues of the Evenki (Tungus) language]. Leningrad, 352 p.

Voskoboinikov, M.G. (1967). O fol'klore evenkov Pribaikal'ia [The folklore of the Evenks in the Baikal region]. In Fol'klor evekov Pribaikal'ia (Zapisal i obrabotal M.G. Voskoboinikov [The folklore of the Evenks in the Baikal region (recorded and processed by M.G. Voskoboinikov)]. Ulan-Ude, Buryat publishing house, 3-21.

Voskoboinikov, M.G. (1973). Kto dal evenkem solntse. Skazki, predaniia i ustnye rasskazy evenkov [Who gave the sun to the Evenks. Fairy tales and stories of the Evenks]. Irkutsk, East-Siberian Publishing House, 248 p.

Whaley, L. J. (2011). Some ways to endanger an endangered language project. In Language and Education, 25(4), 339-348.

Zak, L.M., Isaev, M.I. (1966). Problemy pis'mennosti narodov SSSR v kul'turnoi revoliutsii [Problems of the written languages of the USSR peoples in the cultural revolution]. In Voprosy istorii [Historical issues]. (2), 3-20.

Zakon Krasnoiarskogo kraia “O kul'ture” (s izmeneniiami ot 27 iiunia 2013 goda) [The law of the Krasnoyarsk Krai "About culture" (with ammendments as of June 27, 2013). Available at: http://docs.cntd.ru/document/985011308

Zamaraeva, Iu.S., Reznikova, K.V., Pimenova, N.N. (2017). Istoriia antropologicheskikh issledovanii korennykh narodov Sibiri [History of the anthropological studies of the indigenous peoples of Siberia]. In Sibirskii antropologicheskii zhurnal [Siberian anthropological journal], (1), 6-21. 


\section{Опыт сохранения и развития эвенкийского языка \\ в Эвенкийском муниципальном районе \\ Красноярского края на материале анализа \\ архивных документов Эвенкийского архива}

Ю.С. Замараева

Сибирский федеральный университет Россия, 660041, Красноярск, пр. Свободный, 79

В статье представлен обзор архивных документов, отражающих особенности различных практик сохранения и возрождения эвенкийского языка на территории северных районов Красноярского края (на материале анализа выборки документов по образованию и просвещению из фонда Эвенкийского архива в поселке Тура). Актуальность исследования связана с необходимостью получения наиболее полной информации, раскрывающей динамику культурных и педагогических практик по сохранению северного языка как ядра культуры коренных малочисленных народов Крайнего Севера. Анализ архивных документов, полученных в ходе полевых исследований, проведенных на территории Эвенкии в 2018 году, позволил не только раскрыть базовые тренды процессов сохранения эвенкийского языка, их трансформацию в период с 1930-х г2. (годы образования начиональных округов) до начала 2000-х годов, но и определить сущность проблематики по сохранению исчезающего языка эвенкийской этнокультурной группы в настоящее время. Были обработаны результаты полевых исследований, сделана интерпретация полученных данных. Проводился критический анализ существующих научных исследований, обобщены выводы исследователей, связанных с решением проблемы сохранения и возрождения эвенкийского языка. Особую значимость имеет публикация краткого содержания большого количества архивных документов за период с 1930 г2. по настоящее время.

Ключевые слова: эвенкийский язык, Эвенкийский муниципальный район, просвещение, культурное строчтельство, коренные малочисленнье народы Крайнего Севера.

Исследование выполнено при поддержке АО «Востсибнефтегаз» в рамках реализации проекта по выполнению научно-исследовательских работ «Возрождение эвенкийского языка».

Научная специиальность: 24.00.00 - культурология. 